\title{
Towards an Integrated Theory of Intellectual Property
}

Peter Siegelman

University of Connecticut School of Law

Gideon Parchomovsky

University of Pennsylvania School of Law

Follow this and additional works at: https://opencommons.uconn.edu/law_papers

Part of the Intellectual Property Law Commons

\section{Recommended Citation}

Siegelman, Peter and Parchomovsky, Gideon, "Towards an Integrated Theory of Intellectual Property" (2002). Faculty Articles and Papers. 450.

https://opencommons.uconn.edu/law_papers/450 


\section{VIRGINIA LAW REVIEW}

\begin{tabular}{lll}
\hline \hline VOLUME 88 & NOVEMBER 2002 & NUMBER 7 \\
\hline
\end{tabular}

\section{ARTICLE}

\section{TOWARDS AN INTEGRATED THEORY OF INTELLECTUAL PROPERTY}

\section{Gideon Parchomovsky* and Peter Siegelman**}

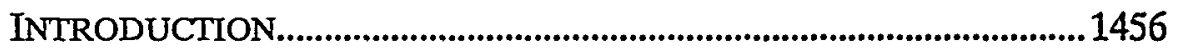

I. THE INSULAR VIEW OF INTELLECTUAL PROPERTY.................1465

A. The Theory ..........................................................................1465

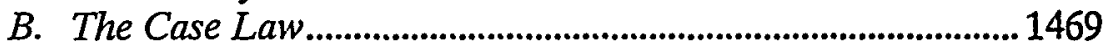

II. A SIMPLE MODEL OF PATENT/TRADEMARK LEVERAGE ........1473

A. The Model .............................................................................1474

B. Refinements and Limitations .............................................. 1481

1. Product Characteristics........................................................ 1481

2. Demand-Side Characteristics ........................................ 1482

3. Rate of Technological Change ........................................ 1484

4. Spillovers and Brand Equity ......................................... 1484

III. EMPIRICAL EVIDENCE OF SYNERGIES .......................................1487

A. Previous Empirical Work.................................................... 1487

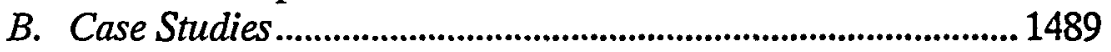

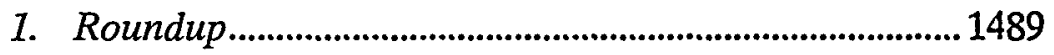

* Associate Professor, University of Pennsylvania Law School.

** Associate Professor, Fordham Law School. We are indebted to Michael Abrantowic, Ian Ayres, Avi Bell, Omri Ben-Shahar, Yochai Benkler, Rachel Brewster, Hanoch Dagan, Zohar Goshen, Doug Licthnian, Kimberly Moore, Mark Patterson, Dan Richman, Alan Schwartz, Henry Smith, Steve Thel, Paul Wolfson, Ben Zipursky, and seminar participants at Georgetown, George Mason, University of Pennsylvania, and Yale for helpful comments. We are especially grateful to Walter Nicholson and Mark Lemley for insightful observation and criticism that substantially improved earlier drafts. Finally, we would like to thank Michael Pereira for excellent assistance, and Fordham Law School for generous financial support. 


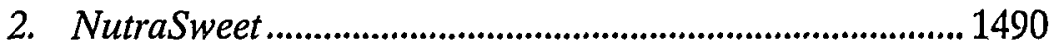

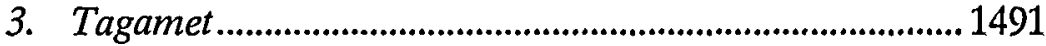

4. Zovirax .......................................................................... 1491

5. Bayer Aspirin...................................................................... 1492

IV. EXTENDING THE ANALYSIS TO TRADE SECRECY AND

COPYRIGHT .......................................................................1493

A. Trade Secrecy ………………………………………................ 1493

B. Copyright ................................................................................ 1497

V. IMPLICATIONS FOR LAW AND POLICY ..........................................1500

A. Pitfalls in the Supreme Court's Approach to Leverage......... 1502

B. Relaxing the Tradeoff Between Dynamic and Static

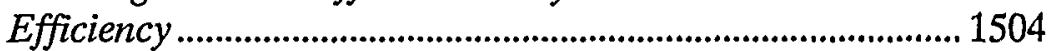

C. Tailoring and Defaults.......................................................... 1508

VI. OBJECTIONS AND ADDITIONAL FACTORS.................................1510

A. Advertising..............................................................................1511

B. Discounting and Dynamic Issues .............................................1513

C. Prices Rise on Expiration of the Patent? ................................ 1515

D. Alternative Proposals..............................................................1517

1. Compulsory Licensing........................................................ 1518

2. Probabilistic Enforcement ................................................... 1519

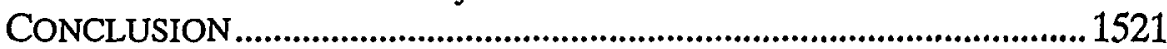

APPENDIX: A DYNAMIC PRICING MODEL .........................................1523

\section{INTRODUCTION}

According to a famous legend, six blimd persons once set out to discern the shape of an elephant. Unable to follow all of its contours, each observed only a single part of the majestic mammal. As a result, the men and women arrived at six different perceptions of the object of their study. Faihing to synthesize their isolated observations, the six could not appreciate the true nature of what they attempted to describe. The moral of the story is that discrete analysis of the parts, accurate though it may be, often distorts one's perception of the whole. The current state of intellectual property theory is a case in point.

In recent years, the importance of intellectual property lawboth as an academic disciphine and as a real world phenomenon- 
has risen meteorically. ${ }^{1}$ Oddly, however, there exists a striking misfit between the academic theory of intellectual property and its use in the real world. Economists and legal scholars tend to treat each of the constituent fields of intellectual property as discrete and insular. ${ }^{2}$ Worse yet, the same insularity has pervaded the United States Supreme Court's intellectual property jurisprudence. Most recently, in TrafFix Devices v. Marketing Displays, Justice Kennedy opined that "[trademark law] does not exist to reward manufacturers for their innovation in creating a particular device; that is the purpose of the patent law and its period of exclusivity." "In this view, patents and copyrights offer limited protection to novel processes or intellectual products, while trademark law protects goodwill. ${ }^{4}$ Those who actually use intellectual property protection, however, appreciate that its various modalities can be combined to yield important synergies: Patents can help create goodwill, and trademarks can be used to appropriate the gains from innovation.'

${ }^{1}$ See Drug Development: Intellectual Property and Patent Protection are New Concerns, Biotech Wk., May 16, 2001, at 10, 10 (reporting that a survey of 272 senior executives in the pharmaceutical, biotechnology, and medical product industries revealed that "the development and protection of intellectual property is seen as the most critical area, as nearly all the senior executives surveyed identified an urgent need to address issues such as protecting proprietary research, valuing intellectual property, and extending patent protection"); Joff Wild, A Yawning Gap That Too Many Companies Fail to Recogmise: Accounting for IP, Fin. Times, June 21, 2001, at 3,3 ("There is a growing belief that, with the increasing influence of the knowledge economy, directors cannot dehiver best value to shareholders unless they know the true value of a company's intellectual property.").

${ }^{2}$ See, e.g., Richard A. Epstein, Intellectual Property: Old Boundaries and New Frontiers, 76 Ind. L.J. 803, 804 (2001) (contending that "intellectual property comprehends at least five or six separate areas" and arguing that "[t]lie mere fact that intellectual property law subsumes these six separate fields does not guarantee that any proposition that holds good for one of these areas will necessarily carry over to a second"); Ruth Okediji, Givers, Takers and Other Kinds of Users: A Fair Use Doctrine for Cyberspace, 53 Fla. L. Rev. 107, 141 (2001) (suggesting that "[c]ourts have generally been careful to articulate distinctions between patents and copyrights").

${ }^{3} 532$ U.S. 23,34 (2001). We would like to note that our criticism is addressed to the Court's disregard of the important commonalities between patent and trademark protection. We agree with the Court's ruling in this case. See discussion infra Section V.A.

"See Doris Estelle Long, First, "Let's Kill All the Intellcctual Property Lawyers!": Musings on the Decline and Fall of the Intellectual Property Empire, $34 \mathrm{~J}$. Marshall L. Rev. 851, 889 (2001) (suggesting that "[t]he TrafFix case raises serious concerns about the future of trademark intersections with both patents and copyrights").

${ }^{5}$ See Siegrun D. Kane, Trademark Law: A Practitioner's Guide $\$ 1: 1.5[D]$, at 1-7 
The conventional view has acknowledged the possibility of employing alternative modes of intellectual property to protect a given business asset-most notably, the availability of patent or copyright protection for software. ${ }^{6}$ But it has largely ignored-and occasionally been hostile to-the possibility of combining different inodes of intellectual property to reinforce one another. Much like the blind persons in the elephant tale, existing analysis has failed to discern the important synergies that flow from combining different nodes of protection. In this Article, we will seek to redress this omission by exploring the consequences of combining various modes of intellectual property protection. We will focus on the possibihty of combining patent and trademark protection by leveraging patents through trademarks, but we will also discuss the synergies between trademarks and both trade secrets and copyrights.

The possibility of leveraging patents through trademarks calls into question the dominant paradigm in intellectual property. Although patent, copyright, and trademark are the three principal subfields in the area of intellectual property, the first two are traditionally deemed to rest on a different economic foundation from the latter. From an economic standpoint, patents and copyrights embody a tradeoff between ex ante and ex post perspectives. Ex ante, society seeks to encourage innovation and expressive creativity by awarding inarket exclusivity over the products that result from these activities. ${ }^{8}$ The cost of copying innovative products and

(3d ed. 2001) ("Trademarks, patents, and copyrights ... [a]ll ... may apply to a single product."). Empirically oriented economists have recognized that patents are not the only or even the most important sources of appropriability. See discussion infra Section III.A.

${ }^{6}$ See, e.g., Craig Joyce et al., Copyright Law 174-75 (5th ed. 2001).

${ }^{7}$ See William M. Landes \& Richard A. Posner, An Economic Analysis of Copyright Law, 18 J. Legal Stud. 325, 326 (1989) (explaining that "[s]triking the correct balance between access and incentives is the central problem in copyright law"); Mark A. Lemley, The Economics of Improvenent in Intellectual Property Law, 75 Tex. L. Rev. 989, 990 (1997) (noting that excessive intellectual property protection deters subsequent innovation as it "freeze[s] development at the first generation of products").

${ }^{8}$ See U.S. Const. art. I, $\S 8$, cl. 8 (empowering Congress " $[t] 0$ promote the Progress of Science and useful Arts, by securing for limited Times to Authors and Inventors the exclusive Riglit to their respective Writings and Discoveries"); see also Mazer v. Stein, 347 U.S. 201, 219 (1954) (explaining that "'[t]he copyright law, like the patent statutes, makes reward to the owner a secondary consideration.'... The economic philosophy behimd the clause empowering Congress to grant patents and copyrights is 
original expressive works is invariably lower than the cost of producing thein initially, and in a competitive market the price will be driven down to the inarginal cost of copying.

Thus, on the one hand, absent exclusivity, inventors and authors will be unable to appropriate the full social value of their products, and too little innovation is likely to result. ${ }^{10}$ On the other hand, once an invention or a copyrighted work has been produced, society wishes to cabin the distortions caused by exclusivity by limiting the duration of patents and copyrights. "Trademark protection, by contrast, is not usually thouglit to einbody a comparable tradeoff. ${ }^{12}$ Rather, its purpose is to permit firms to estabhish or maintain goodwill and to preserve their reputation anong consumers. ${ }^{13}$ Thus, tradeinark protection is, in principle, infinite in duration. ${ }^{14}$

the conviction that... [it] is the best way to advance public welfare through the talents of authors and inventors in 'Science and useful Arts."') (citation omitted).

${ }^{9}$ See Carl Shapiro \& Hal R. Varian, Information Rules: A Strategic Guide to the Network Economy 3 (1999). Professors Shapiro and Varian observe that "production of an information good involves high fixed costs but low marginal costs." For example, "100-million dollar movies can be copied on videotape for a few cents." Id.

${ }^{10} \mathrm{Or}$, as Judge Richard Posner succinctly explained the rationale underlying the patent system, "the manufacturer ... will not sow if he won"t bc able to reap." Richard A. Posner, Economic Analysis of Law $\$ 3.3$, at 43 (5th ed. 1998).

${ }^{11}$ The limited duration is not dictated by economies alone, of course; it is mandated to some degree by the Intellectual Property Clause in the Constitution. See U.S. Const. art. I, § 8, cl. 8. Even before the ratification of the Constitution and the adoption of the U.S. patent and copyright laws, Englisli jurists struggled to reconcile ex ante incentives and ex post distortions. See Cary v. Longman, 102 Eng. Rep. 138, 140 n.(b) (1801) (Lord Kenyon, C.J.) ("The rule of decision in this case is a matter of great consequence to the country. In deciding it we must take care to guard against two extremes equally prejudicial; the one, that men of ability, who have employed their time for the service of the community, may not be deprived of their just merits, and the reward of their ingenuity and labour; the other, that the world may not be deprived of improvements, nor the progress of the arts be retarded."') (quoting Sayre $v$. Moore, 102 Eng. Rep. 139, 140 (1785) (Lord Mansfield, C.J.)).

${ }^{12}$ A trademark does not "depend upon novelty, inventiou, discovery, or any work of the brain. It requires no fancy or imagination, no genius, no laborious thought." Trade-Mark Cases, 100 U.S. 82, 94 (1879). "Rather, trademark protection is awarded merely to those wlio were the first to use a distinctive mark in commerce." Robert P. Merges et al., Intellectual Property in the New Technological Age 525 (1997).

${ }^{13}$ See William M. Landes \& Richard A. Posner, Trademark Law: An Economic Perspective, 30 J.L. \& Econ. 265, 270 (1987) ("The value of a trademark is the saving in [consumer] search costs made possible by the information or reputation that the trademark conveys or embodies about the brand (or the firm that produces the brand."). Some, however, liave criticized recent developments in trademark law as going substantially beyond this purpose, allowing trademarks to become an anti- 
Despite the different economic and legal theories underlying them, however, we contend that both patents and trademarks allow firms to appropriate the benefits of investment in Research and Development ("R\&D") and product quality. ${ }^{15}$ While the effect of patents on investment in R\&D is well recognized, ${ }^{16}$ the complementary effect of trademarks on innovation has received virtually no attention. ${ }^{17}$ Combiming patent and trademark protection can create two important types of synergies for a firm. First, the existence of a patent can reduce the cost of establishing a strong trademark because the exclusivity granted by the patent may lower the advertising expenditures necessary to create a dominant brand. ${ }^{18}$

competitive force. See, for example, Mark A. Lemley, The Modern Lanham Act and the Death of Common Sense, 108 Yale L.J. 1687 (1999), which draws heavily on insights developed in Ralph S. Brown, Jr., Advertising and the Public Interest: Legal Protection of Trade Symbols, 57 Yale L.J. 1165 (1948).

${ }^{14}$ See Kane, supra note $5, \S 1: 1.5[\mathrm{D}]$, at 1-7 ("Trademark law, unlike patent and copyright law, confers a perpetual right. So long as the trademark continues to iden. tify a single source, the user of a confusingly similar mark is liable for trademark in* fringement.").

${ }^{15}$ See Kenneth W. Dam, The Economic Underpinnings of Patent Law, 23(1) J. Legal Stud. 247, 247-49 (1994). Professor Dam notes that the patent system solves the "appropriability problem"-the problem that innovation would be inhibited if a firm could not recover the costs of invention-by creating property rights in inventions. The solution, however, also entails three secondary economic problems: monopoly leading to a deadweight loss, rent-seeking, and inhibition of future innovation.

${ }^{16}$ For example, the leading textbook on industrial organization describes the incentive effects of patents as follows:

The funds supporting invention and the commercial development of inventions are front-end "sunk" investments; once they have been spent. they are an irretrievable bygone. To warrant making such investments, an individual inventor or corporation must expect that once commercialization occurs, product prices can be held above postinvention production and marketing costs long enough so that the discounted present value of the profits (or more accurately, quasi rents) will exceed the value of the front-end investment. In other words, the investor must expect some degree of protection from competition, or some monopoly power. The patent holder's right to exclude imitating users is intended to create or strengthen that expectation.

F.M. Scherer \& David Ross, Industrial Market Structure and Economie Performance 622 (3d ed. 1990).

${ }^{17}$ Commentators, however, have recognized that trademarks provide an incentive to invest in existing goods. See J. Thomas McCarthy, McCarthy on Trademarks and Unfair Competition $\S 2: 4$, at 2-4 (4th ed. 2002) (noting that trademarks "create an incentive to keep up a good reputation for a predictable quality of goods" and thereby "fix responsibility" for low quality products).

${ }^{18}$ The relationship between advertising and inonopoly power is notoriously complex, but any given amount of advertising by Acme Widgets is likely to be more suc- 
Establishing brand loyalty may be easier under conditions of exclusivity than when one lias to fend off numerous rivals. ${ }^{19}$ Xerox, for example, succeeded in establishing such strong branding for its patented photocopy machines that its mark lias become virtually synonymous with the product, and almost fell into the public domain for genericism after consumers began to use "xerox" as a verb and a noun. ${ }^{20}$

Conversely, brand recogirition can be used to extend the protection afforded by patents well beyond the legal protection period. For example, consumers remained loyal to Bayer Aspirin for decades after it went off patent, in spite of the existence of identical generic drugs that sold for much less and despite the fact that the "Aspirin" mark liad been pronounced generic. ${ }^{21}$ It is this type of synergy that will be the main focus of this Article. The liohstic view of intellectual property that we will develop in this Article enables us to offer four novel insights about the theory and practical use of intellectual property law.

In Part I, we will observe that the existence of synergies between patents and trademarks cliallenges the conventional wisdom that the economic effect of a patent grant is limited to the statutory protection term of twenty years. Combining patent and tradeunark

cessful in attracting customers if it has $100 \%$ of the market than if it shares the market with other firms whose advertising competes with or offsets its own. In this sense, competitive advertising has aspects of the prisoner's dilemma-each brand's advertiseinents inay largely serve to offset those of its rivals, and all established firms might be better off if they could agree (without violating antitrust laws) to advertise less, or not at all. See Lemley, supra note 13, at 1691 n.21; see also Douglas G. Baird et al., Game Theory and the Law (1994) (explaining the application of the prisoner's dilemma, equilibrium solutions, and game theory generally to traditional legal problems).

There are non-strategic considerations that may cut in the other direction, however, and lead a monopolistic industry to advertise more (per dollar of sales) than a competitive one. See Robert Dorfman \& P.O. Stemer, Optimal Advertising and Optimal Quality, 44 Am. Econ. Rev. 826 (1954).

${ }^{19}$ See discussion infra Section III.B.

${ }^{30}$ See Paul Goldstein, Copyright, Patent, Trademark and Related State Doctrines: Cases and Materials on the Lav of Intellectual Property 230 (rev. 3d ed. 1993) (relating the story of the "Xerox" trademark's close encounter with the public domain).

${ }^{21}$ See Bayer Co. v. United Drug, 272 F. 505 (S.D.N.Y. 1921) (finding Aspirin a generic mark with respect to consumer, though not producer, sales); see also Charles $C$. Mann \& Mark L. Plummer, The Aspirin Wars: Money, Medicine, and 100 Years of Rampant Competition (1991) (recounting the intellectual property history of Aspirin). 
protection may afford patentees a considerably longer period of protection than is commonly assumed. An important implication of this observation is that if the present statutory patent duration was chosen to reflect the optimal tradeoff between rewarding innovation and limiting monopoly power, then patentees who extend their patent with a successful trademark are actually receiving more monopoly power than the statute contemplates. We use the term "trademark leverage" to describe patentees' ability to charge supracompetitive prices even after the patent has lapsed and the invention is protected only by a trademark.

In Part II, we will submit that, counterintuitively, the enhanced protection afforded by such leveraged patents is actually welfareenhancing. The reason is that leveraging patents through trademarks generates incentives for patentees to price more competitively over the patent life, without adding monopolistic distortions in the trademark period. In short, leverage allows for a more favorable tradeoff between mcentives to innovate and monopolistic pricing than is traditionally envisioned.

Economic analysis of patent law-traditionally conducted on a stand-alone basis-assumes that the patentee will maximize her rents during the term of protection by charging the monopoly price for the imvention. ${ }^{22}$ Specifically, the patentee will restrict the quantity of output below the competitive level, to the point at which its marginal revenue is equal to its marginal cost. This generates a social deadweight loss, ${ }^{23}$ because some consumers who would be willing to pay more for the product than its marginal cost are unable to purchase it from the monopolistic patentee; the gains from trade that would be available in a competitive market are lost as a result of the patentee's monopoly. ${ }^{24}$

The possibihty of leveraging patents through traclemarks transforms the analysis. When patents can be extended through creation of brand loyalty, the patentee will strive to maximize her rents not

\footnotetext{
${ }^{22}$ Robert Cooter \& Thomas Ulen, Law and Economics 128 (3d ed. 2000).

${ }^{23}$ Deadweight loss arises from the fact that, in maximizing profits a monopolist will cut back on the quantity it produces, thereby refusing to sell to some consumers who would be willing to pay more than the cost of producing the good in question. The difference between consumer valuation and producer cost, for these foregone sales, is the economist's measure of the deadweight loss of monopoly. See George J. Stigler, The Theory of Price 197 (3d ed. 1966).

${ }^{24} \mathrm{Id}$.
} 
over the twenty-year patent term, but rather over the combined period of patent and trademark protection. Hence, a forwardlooking patentee will consider not only current output, but also the effects of current output on future demand. Specifically, a profitmaximizing patentee will charge less than the monopoly price during the patent period if doing so enhances its branding and leads to higher profits over the long run. Thus, we posit that even patentees who wield monopoly power by dint of the legal exclusivity conferred upon them may prefer not to extract the full monopolistic rent afforded to them by the patent grant.

In Part III, we will demonstrate that this prediction is not merely of theoretical significance: It finds support in commercial reality. Evidence from various industries shows that, in some circumstances, patentees behave in accordance with our analysis, raising output above the monopohistic level (and lowering prices) in order to increase their future profits through trademark protection.

Critically, the welfare gain from lower prices is not offset by a corresponding loss attributable to a longer duration of protection. Once the patent expires, the former patentee's loyal customers pay a higher-than-market price for the off-patent product, but the marginal (new) customers buy from the new entrants, who charge the competitive price and eliminate any deadweight loss. In other words, the ability to combme patents and trademarks makes it possible for the patentee to shift profits from the "distortionary" patent period to the competitive trademark period, where the patentee can charge higher-than-competitive prices without reducing the overall quantity supphed. ${ }^{25}$ As a result of this shift, the deadweight loss in the patent period is lowered, without any accompa-

\footnotetext{
${ }^{25}$ Put another way, the patentee's loyal customers are subject to a kind of price discrimination, and, thus, are worse off than they would be if they could buy at the competitive price. The higher prices they pay, however, are a pure transfer to the patentee, with no efficiency consequences. See Richard A. Posner, Antitrust Law 203-04 (2d ed. 2001) (discussing price discrimination in the licensing of patents); Louis Kaplow, The Patent-Antitrust Intersection: A Reappraisal, 97 Harv. L. Rev. 1813, 187381 (1984) (discussing price discrimination and patent law); cf. Michael J. Meurer, Copyright Law and Price Discrimination, 23 Cardozo L. Rev. 55 (2001) (discussing price discrimination and copyright law). Readers of this Article may be particularly interested in Stanley Liebowitz's findings on the role of price discrimination in markets for academic journals. See S.J. Liebowitz, Copyright Law, Photocopying, and Price Discrimination, in 8 Research in Law and Economics: The Economics of Patents and Copyrights 181 (John Palmer \& Richard O. Zerbe, Jr. eds., 1986).
} 
nymg cost in the subsequent trademark period. Patent leveraging thus increases welfare.

In Part IV, we will demonstrate that the same welfare-enhancing effect that arises from coinbining patent and trademark protection also occurs when trade secrets and trademarks are combined. Although trade secrecy does not have inherent time limits, it lapses if the protected information falls into the hands of conpetitors, either through a breach of secrecy or through reverse-engineering. For the purpose of our analysis, this risk serves the same function as the time limitation on patents: It nitigates the incentive of the trade secret holder to price noonopolistically. Realizing that the trade secret may expire at any given time, a rational trade secret owner will prefer not to price monopolistically during the trade secrecy period if doing so will sufficiently increase the long terin value of her brand. In this case, too, the net welfare effect of combining the two modes of protection may be positive. ${ }^{26}$

We will examine in Part V how legal policy should take account of the possibility that patent and tradenuark protection can be conibined. We argue that the Supreme Court's failure to appreciate the positive synergies between patents and trademarks led it badly astray in the landmark case of Singer Manufacturing Co. v. June Manufacturing $\mathrm{Co}^{27}$ In expressing its strong disapproval of Singer's strategy of leveraging its patents through a trademark, the Court concluded that the "coincidence between the expiration of the patents and the appearance of the trademark ... tends to create a strong implication that the company ... [acted] in order tliereby to retain ... the real fruits of the nionopoly when that monopoly had passed away." 28 According to our analysis, the Court erred in condemning a practice that increases welfare. Thus, Singer and its progeny should be overturned.

Moreover, our analysis counterintuitively suggests that efficiencyminded policymakers would be justified in either shortening or lengthening the patent term, or indeed leaving it at its present length. Any of these is a defensible alternative because leverage

\footnotetext{
${ }^{26}$ Although there may be some instances in which copyright and trademark protection can be combined, leverage does not seem to apply to copyright protection generally. See discussion infra Section IV.B.

163 U.S. 169 (1896).

${ }^{28}$ Id. at 181.
} 
creates both greater incentives to innovate and a lower static deadweight loss, thereby generating a inore favorable tradeoff between these two goals, which policymakers may wish to exploit in a variety of ways.

Leverage pushes out the possibility frontier, allowing policymakers a range of desirable options. In particular, we propose a selfselection mechanism that allows society to offer patentees the same level of profits as the current system at a lower cost in deadweight loss. ${ }^{29}$ Alternatively, policymakers might opt for a higher level of profits for patentees, with no increase in deadweight loss. We offer an illustrative example of low such policies might be implemented.

Finally, in Part VI, we will take on a series of possible objections to our argument, including the presence of advertising, the extension of the model to a inore reahistic inulti-period world with discounting, and the einpirical finding that-at least for some products-prices rise, rather than fall, on expiration of a patent. None of these, we show, requires substantial modification of our conclusions.

\section{THE INSULAR VIEW OF INTELLECTUAL PROPERTY}

\section{A. The Theory}

Intellectual property law rests on an elegant model that divides the field into three principal subfields-copyright, patent, and trademark-each protecting a distinct subject matter and promoting a unique social goal. Copyright law protects expressive works; patent law protects functional products, processes, and designs; and trademark law protects information about the source of goods and products. The separation among these three subfields is reinforced by the different prerequisites to securing each mode of protection. Copyright protection requires works to be original, ${ }^{30}$ minimally creative, and fixed in a tangible medium of expression..$^{32}$ Patent

\footnotetext{
${ }^{29}$ See discussion infra Section V.C.

${ }^{30} 17$ U.S.C. $\$ 102(2000)$.

${ }^{31}$ See Feist Publ'ns v. Rural Tel. Serv. Co., 499 U.S. 340,345 (1991) (explaining that "[o]riginal, as the term is used in copyright, means only that the work was independently created by the author ... and that it possesses at least some minimal degree of creativity").

${ }^{32} 17$ U.S.C. $\$ 102$ (2000).
} 
protection extends to inventions that are new,,$^{33}$ useful, ${ }^{34}$ and nonobvious ${ }^{35}$ to a person skilled in the relevant art. ${ }^{36}$ Trademark protection is sparked by the use of a mark in trade. ${ }^{37}$ Furthermore, the three subfields differ in the duration of the protection they afford. Copyright protection lasts for the life of the author plus seventy years. ${ }^{38}$ Patent protection extends twenty years from the date of filing for utility patents, ${ }^{39}$ and fourteen years from the date of issuance for design patents. ${ }^{40}$ Trademark protection continues potentially forever, as long the inark is used in trade. ${ }^{41}$

The economic rationale for copyrights and patents is also assumed to be different from the rationale for trademarks. Copyrights and patents are predicated on the need to provide an economic incentive for the creation of public goods such as inventions and expressive works. ${ }^{42}$ Since expressive works and inventions con-

${ }^{33} 35$ U.S.C. $\$ 101$ (2000).

${ }^{34} \mathrm{Id}$.

${ }^{35}$ Id. $\& 103$.

${ }^{36}$ Id.; see Robert P. Merges \& Richard R. Nelson, On the Complex Economics of Patent Scope, 90 Colum. L. Rev. 839, 844 (1990) ("During prosecution of a patent, a Patent Office examiner reviews an application to determine what is patentable. To be patentable an invention must meet all the statutory requirements for patentability: novelty, utility and non-obviousness."). In addition, "[w]hile decisions regarding what [claims] to allow are constramed by a number of legal principles, and by the invention itself, in many cases the Patent Office has considerable room for discretion." Id. at 840.

${ }^{37}$ See, e.g., Jane C. Ginsburg et al., Trademark and Unfair Competition Law 45 (3d ed. 2001) ("Simply by using a mark on or in connection with goods, or by displaying the mark in the sale or advertising of services, you can automatically acquire trademark rights in the geographic area of use.").

${ }^{38} 17$ U.S.C. $\$ 302(2000)$.

${ }^{39} 35$ U.S.C. $\$ 154(2000)$.

${ }^{40}$ Id. $\S 173$.

${ }^{41}$ See, e.g., Ginsburg et al., supra note 37, at 46 (noting that "[t]raclemark rights continue indefinitely").

${ }^{42}$ See, e.g., Kenneth J. Arrow, Economic Welfare and the Allocation of Resources for Invention, in The Rate and Direction of Inventive Activity: Economic and Social Factors 609 (1962); Robert M. Hurt \& Robert M. Schuchman, The Economic Rationale of Copyright, 56 Am. Econ. Rev. (Papers \& Proc.) 421, 425 (1966) ("The general welfare will ... be enhanced by enacting copyright legislation which encourages the creation and publication of manuscripts that otherwise would not have come into existence."); Landes \& Posner, supra note 7, at 326; see also Richard P. Adelstein \& Steven I. Peretz, The Competition of Technologies in Markets for Ideas: Copyright and Fair Use in Evolutionary Perspective, 5 Int'l Rev. L. \& Econl. 209, 218 (1985) (discussing the similarities between intellectual goods and traditional public goods). But see Tom G. Palmer, Intellectual Property: A Non-Posnerian Law and Economics 
tain information-the quintessential public good-absent legal protection, competitors would copy such works without incurring the initial costs of producing them. Unauthorized reproduction would drive down the market price to the cost of copying, original authors and inventors would not be able to recover their expenditures on authorship and $R \& D$, and, as a result, too few inventions and expressive works would be created.

To make matters worse, many of the inventions that would not be produced absent intellectual property protection are likely to be of great social value. Socially important inventions often implicate not only large expenditures, but also a high level of risk. Inventors, who work under conditions of extreme uncertainty, do not know, ex ante, whether the $R \& D$ process will yield the anticipated result. Nor do they know how the invention will fare commercially. ${ }^{43}$ Subsequent copiers, however, confront no similar risks since they have the privilege of being able to reproduce, risk-free, only those inventions with proven commercial success.

Copyright law and patent law eliminate the inherent advantage of copiers, and thereby restore the incentive to innovate. By creating and enforcing exclusive rights in intellectual goods, copyrights and patents not only stifle unauthorized copying, but also enable authors and inventors to charge for the use of their works. In addi-

Approach, 12 Hamline L. Rev. 261, 273-87 (1989) (arguing that intellectual works do not share the distinguishing attributes of public goods).

Public goods are defined by two distinctive characteristics: non-rivalry in consumption and non-excludability of benefits. See, e.g., Richard Cornes \& Todd Sandler, The Theory of Externalities, Public Goods, and Club Goods 6-7 (1986). A good is nonrival in consumption when consumption by one person does not diminish the consumption opportumities available to others. See id. at 6 .

A good displays non-excludable benefits when individuals who have not paid for it cannot be prevented from availing themselves of its benefits. See id. It should be noted that the impossibility of exclusion is laardly ever absolute. When exclusion by contract is considered, very few goods, if any, display non-excludable benefits in the strict sense of the term. Thus, it is more accurate to describe goods as displaying nonexcludable benefits when it is prohibitively costly to bar non-payers from enjoying the good. See Patrick Croskery, Institutional Utilitarianism and Intellectual Property, 68 Chi.-Kent L. Rev. 631, 632 (1993). The non-excludability property of public goods implies that they will be under-produced by the market.

${ }^{45}$ See Lemley, supra note 7, at 994 (noting that "[i]nvention and creation require the investment of resources-the time of an author or inventor, and often expenditures on facilities, prototypes, supplies, and the like[,]" and therefore, absent intellectual property protection, creators or inventors would "live[ in constant peril of discovery and disclosure"). 
tion, copyright law and patent law provide the necessary foundation for market exchange between providers and consumers of intellectual goods. The development of a market, in turn, produces two desirable effects: It increases the return on authorship and innovation, and it lets the forces of supply and demand set the price of intellectual goods.

In contrast, the economic justification for trademark protection is rather different. Unlike patent and copyright protection, which seek to spur the creation of inventions and expressive works, trademark protection purports to enhance competition among providers of goods and services. ${ }^{44}$ By identifying the source of goods and services, trademarks promote competition in two related ways. First, trademarks enable businesses to convey information to consumers about the quahity of products and services, reducing consumers' search costs. ${ }^{45}$ This informational function of trademarks is especially valuable in the context of "experience goods"-products whose attributes consumers cannot discern before purchasing them ${ }^{46}$-where consumers rely on prior experience in deciding among competimg brands.

Second, trademarks allow consumers to associate product and service attributes with certam firms and base their consumption decisions on this association. For this reason, on the supply side, trademark protection spurs firms to maintain and improve the quality of their products and services. ${ }^{47}$ The availability of trade-

${ }^{44}$ See S. Rep. No. 79-1333, at 3 (1946); H.R. Rep. No. 79-219, at 2 (1945) ("Trademarks defeat monopoly by stimulating competition."). For arguments that excessive trademark protection can have anticompetitive effects, see Brown, supra note 13, and Lemley, supra note 13.

${ }^{45}$ See, e.g., Nicholas Economides, Trademarks, in 3 The New Palgrave Dictionary of Economics and the Law 601, 602 (Peter Newman ed., 1998) (noting that trademarks "facilitate and enhance consumer decisions"); William P. Kratzke, Normative Economic Analysis of Trademark Law, 21 Memphis St. U. L. Rev. 199, 214-17 (1991); see also George Stigler, The Economics of Information, 69 J. Pol. Eccn. 213, 224 (1961) (discussing reputation as a method of saving on search costs).

${ }_{46}$ Phillip Nelson, Advertising as Information, 82 J. Pol. Econ. 729, 730 (1974) [hereinafter Nelson, Advertismg as Information]. A "search good," in contrast, is onc whose important attributes inay be ascertained before purchase or use. Id. The terms "experience good" and "search good" were originally coined by Professor Nelson in 1970. See Phillip Nelson, Information and Consumer Behavior, 78 J. Pol. Econ. 311, 319 (1970).

${ }^{47}$ See Landes \& Posner, supra note 13, at 269-70. Landes and Posner note that trademarks have a self-enforcing quality because "they denote consistent quality, and 
mark protection protects firms against free-riding by competitors, enabling them to reap the fruits of their investment in superior products and services. Furthermore, trademark protection provides firms with an imcentive to estabhish brand recognition and loyalty by "educating" consumers about the virtues of their products. Thus, trademarks constitute an important channel of communication between firms and consumers, with the attendant twin effects of motivating the former to improve the quahty of their products and services, and enabling the latter to differentiate among various products on the market.

Law and Economics scholars have largely ignored the existence of synergies among the various types of intellectual property protection. ${ }^{48}$ For example, the leading Law and Economics text suggests that the economic justification for patents is that they are "temporary monopol[ies] that reward invention." trademarks are designed to "lower consunier search costs and create an imcentive for producers to supply goods of high quality.".so

\section{B. The Case Law}

The insular view of intellectual property has also been a persistent theine in the Supreme Court's intellectual property jurisprudence. The tone was set in three classic decisions. In Baker v. Selden, the Supreme Court was asked to decide whether the respondent, Selden, could obtain copyright protection for a system of bookkeeping by means of a book in which the system was explamed. ${ }^{51}$ Pointing to the different subject matters of copyright and patent protection, and the different requirements for each, the

a firm has an incentive to develop a trademark only if it is able to maintain consistent quality." Id. at 270.

${ }_{48}$ There has, however, been some appreciation of these synergies in the mainstream economics literature. See discussion infra Part III.

* Cooter \& Ulen, supra note 22 , at 128 . The authors also note that "the price [of a patented good] falls and the quantity increases as soon as the patent expires." Id. (cmpliasis added).

${ }^{50}$ Id. at 137 . Similarly, a recent survey article notes that, "[u]nlike patents and copyrights ... trademark protection did not originate as an incentive for innovation or creativity ... [Instead, $t$ ]he primary function of tradeinarks is to provide rules of orderly inarketing...." Stanley M. Besen \& Leo J. Raskind, An Introduction to the Law and Economics of Intellectual Property, 5 J. Econ. Persp. 3, 20-21 (1991).

sl 101 U.S. 99 (1879). 
Court refused to allow copyright protection for patentable subject matters, repeatedly emphasizing the need to keep the province of copyright separate from that of patents. ${ }^{52}$ It concluded that to do otherwise would amount to "a fraud upon the public.,"53

Fifteen years later, in Singer Manufacturing Co. v. June Manufacturing Co., the Supreme Court elucidated the relationship between patents and trademarks. ${ }^{54}$ The issue confronting the Court in Singer was whether a mark that had been used in connection with a patented subject matter becomes generic at the expiration of the patent. ${ }^{55}$ While the Court stopped short of ruling that any mark associated with a patented product falls into the public domain when the patent expires, it established that the existence of a previous patent is a factor to be weighed in determining the validity of a mark. Specifically, the Court ruled that the "Singer" mark fell into the public domain at the expiration of the patents on the sewing machimes. ${ }^{56}$

Critical to this finding was the Court's strong disapproval of Singer's attempt to leverage its patents through trademarks by establishing the name "Singer" and the shape of its machines as trademarks in the years preceding the expiration of its patents. The proximity in time between the appearance of the traclemark on the machines and the impending expiration of its patents implied to the Court that Singer had sought to extend the benefits of its monopoly beyond the patent protection period. ${ }^{57}$ Rephrased in economic terms, the Court acted to bar Singer from enjoying monopolistic rents-what the Court called "the real fruits of the monopoly" ${ }^{58}$-in the post-patent period.

Nearly four decades later, the Supreme Court further solidified the conceptual separation between patents and trademarks in $\mathrm{Kel}$ -

\footnotetext{
${ }^{52}$ Id. at 104-05.

${ }^{53} \mathrm{Id}$. at 102.

s4 163 U.S. 169 (1895).

${ }^{55}$ Id. at $184-85$.
}

${ }^{56} \mathrm{Id}$. at 186 . The operative result of this finding was to allow the clefendant to affix the "Singer" mark to its products, so long as it clearly indicated that it, not Singer, was the manufacturer of the machine. For a case suggesting that the "Singer" mark was subsequently resurrected, see Singer Mfg. Co. v. Redlich, 109 F. Supp. 623 (S.D. Cal. 1952).

${ }_{57}^{57}$ Singer, 163 U.S. at 181.

${ }^{58}$ Id. 
logg Co. v. National Biscuit Co. ${ }^{59}$ In Kellogg, the Court was given an opportunity to revisit its ruling in Singer when Kellogg brought a tradeınark infringement suit, post-patent expiration, against $\mathrm{Na}$ bisco for using the mark "Shredded Wheat." Construing Singer broadly, the Court enunciated that upon the expiration of a patent "there passe[s] to the public... not only the right to inake the article as it was made during the patent period, but also the right to apply thereto the name by which it had become known." Effectively, the Court's decision may be read to have established a per se rule that a mark designating a patented product becomes generic at the end of the patent term. ${ }^{61}$

These cases prompted soine leading intellectual property scholars to suggest that "the federal regimes are preemptive of each other-that the same innovation cannot be protected by both patent and copyright law, or by both patent and trademark law.,"62 Subsequent decisions by lower courts, however, repudiated the preemption theory as between copyright and patent. In Application of Yardley, the Umited States Patent and Trademark Office ("PTO") refused to issue a design patent on an ornamental wristwatch on the ground that the Spiro Agnew caricature featured on the watch face had been registered independently in the United States Copyright Office. ${ }^{63}$ In reversing the PTO, the Umited States Court of Customs and Patent Appeals explamed that Congress intended there to be a degree of subject inatter overlap between the protection afforded by design patents and that granted by copy-

\footnotetext{
${ }^{59} 305$ U.S. 111 (1938).

${ }^{60} \mathrm{Id}$. at 118.
}

${ }^{61}$ This extreme view, articulated in Goldstein, supra note 20, at 232-33, would suggest that when the patent on Prozac expired in August of 2001, new producers could market their chemically identical product (fluoxetine) as "Prozac." In other words, Eli Lilly's exclusive right to use the brand name Prozac would vanish with the expiration of its patent. The fact that no generic entrants ever market their product under the original trade name suggests that Professor Goldstein may not be correct (or that producers are all too risk-averse to find out). It is possible, however, that the Kellog Court's broad rule stems from the fact that the mark "Shredded Wheat" was descriptive, if not generic, from the beginning.

${ }^{6}$ Rochelle Cooper Dreyfuss \& Roberta Rosenthal Kwall, Intellectual Property: Trademark, Copyright and Patent Law 848 (1996); see also Michael J. Kline, Requiring an Election of Protection for Patentable/Copyrightable Computer Programs (Part I), 67 J. Pat. \& Trademark Off. Soc'y 280 (1985) (arguing that an election abandoning copyright protection should be made upon the issuance of a patent).

493 F.2d 1389, 1391-92 (C.C.P.A. 1974). 
right. ${ }^{64}$ Accordingly, the court ruled that the "election of protection" doctrine, on which the PTO relied in denying the patent, is "in direct conflict with the clear intent of Congress."

Over two decades later, in 1995, the Copyright Office finally followed the PTO and announced that it was abandoning the "election of protection" doctrine, under which it had refused for many years to register copyright claims over pictorial, graphic, and sculptural designs for which design patents had been issued. ${ }^{66}$ These policy changes have opened the way for concurrent copyright and patent protection for the same subject matter, and have proven to be of great significance in the context of computer software. ${ }^{67}$

Importantly, the Supreme Court's rulings in Singer and Kellogg, as to the illegitimacy of leveraging patents through trademarks, have not been revisited. Thus, while businesses can choose between trademark and patent protection, and while they may be able to secure concurrent trademark and patent protection for functional designs, they likely cannot coinbine tradeinark and patent protection sequentially to leverage their patents. Atteinpts to leverage patents through trademarks will be frowned upon by the courts.

In suin, the Supreme Court's intellectual property jurisprudence suffers froln three principal defects. First, the insistence on viewing copyright, patent, and trademarks as protecting distinct social goals-a position shared by many Law and Economics scholars-is in inany cases simply wrong. As we will show, trademark protection also spurs innovation and can complement the incentive provided by patents to expend resources on $R \& D$.

Second, the Court's emphasis on protection, rather than on value, has driven a wedge between the legal system's approach to

${ }^{64}$ Id. at 1394 (citing Mazer v. Stein, 347 U.S. 201 (1954)).

${ }^{65}$ Id.

${ }^{66}$ Registration of Claims to Copyright, 37 C.F.R. $\$ 202.10$ (2002); see Douglas R. Wolf, The Doctrine of Elections: Has the Need to Choose Been lost?, 9 Cardozo Arts \& Ent. L.J. 439, 463-64 (1991) (discussing the Copyright Office's acceptance of the "election of protection" doctrine as of 1991).

${ }^{6}$ See Mark A. Lemley et al., Software and Internet Law 38-45 (2000) (explaining that various substantive areas of law may be employed to protect computer software, including trade secret law, copyright law, patent law, trademark law, sui generis laws, and contract law).

${ }^{68}$ See discussion infra Section V.A. 
intellectual property and that of the business community. Speaking to managers of intellectual property, Professors Carl Shapiro and Hal Varian advise that, "your goal should be to choose the terms and conditions that maximize the value of your intellectual property, not the terms and conditions that maximize the protection. ${ }^{369}$ Instead, courts have wrongly adopted rules that are hostile to value maximization.

Third, and inost importantly, the judicial treatment of intellectual property is not helpful for pohcy analysis. The Supreme Court's formalistic approach has prevented it from evaluating the welfare implications of combining different modes of intellectual property protection. We will demonstrate that combining different modes of protection may give rise to important synergies that have so far gone unrecognized. These synergies, contrary to the prevailing view, enhance social welfare.

\section{A Simple Model of PATENT/TRADEMARK LEVERAgE}

The combination of patent and trademark protection generates two complementary advantages for the intellectual property holder. First, the limited monopoly afforded by patent protection may facilitate the establishment of brand loyalty during the patent life. Thus, patent protection enhances the value of the coinpany's mark. Second, brand loyalty enables patentees to preserve some of their market share after the patent protection expires. This implies that trademark protection can suppleinent patent protection. The net effect of combining patents and trademarks is stronger protection than that afforded by either alone. Surprisingly, however, we demonstrate that despite this stronger protection for patentees, leveraged patents are actually welfare-enhancing, since they mitigate patentees' disposition to price monopohstically.

To see why trademark protection lessens the incentive to price monopolistically, imagine a world without any tradeinarks at all. In sucl a world, when the patent on an invention expires, anyone can produce and market it under the patentee's inark. To take a concrete hypothetical example, when Prozac went off patent, any pliarmaceutical company would have been able to produce the drug and market it under Eli Lilly's "Prozac" mark; no generics

${ }^{69}$ Shapiro \& Varian, supra note 9, at 5. 
would exist. The absence of trademark protection would affect patentees in two ways. First, patentees would take full advantage of the patent grant by pricing monopolistically while they were able to do so. Second, patentees would have less incentive to invest in the quality of their products and services. Without brands, brand loyalty is meaningless.

The introduction of tradeniark protection extending beyond the patent life conipletely transforms the analysis. By enabling compamies to create brand loyalty, trademark protection not only makes it rational for them to mvest in the quahty of their products, but also puts pressure on them to increase the number of sales during the patent term to broaden their loyal customer base for the postpatent period. Thus, trademark protection may reduce the social deadweight loss generated by patent protection. In this Part, we present a formal model that shows how leveraging patents through trademarks may improve social welfare. We then support our theoretical results with empirical evidence from various sources. Finally, we discuss how various factors such as advertising and a more sophisticated dynamic model affect our findings.

\section{A. The Model}

To illustrate the effect of trademarks on patents, we construct a stylized two-period model. ${ }^{70}$ In the first period, the firm can use patent protection to select the feasible price-quantity combination that maximizes its profits. In the second period, the patent protection lapses, and the firm nust rely exclusively on brand loyalty created earlier, plus trademark protection, to secure supracompetitive profit. ${ }^{11}$ We show that the existence of trademark protection does

\footnotetext{
${ }^{70}$ For the sake of simplicity, we condense the twenty-year statutory period of patent protection into a single period and ignore issues of discounting, which are peripheral to our basic insight. In the Appendix, we offer a dynamic multi-period model in which we consider each year of patent protection separately, and allow the monopolist to choose optimal quantity over time, allowing for discounting. Our dynamic model demonstrates essentially the same result as above, although the assumption of long. lived consumers is in tension with the existence of brand loyalty. See infra Appendix.

${ }^{71}$ Although the patentee is assumed to be forward-looking, consumers are not. Hence, we do not model consumers as choosing between buying today versus buying next period. Such consumer "myopia" is a standard assumption in these contexts-see Paul Klemperer, Markets with Consumer Switching Costs, 102 Q.J. Econ. 375 (1987); Jean Gabszewicz et al., Sequential Entry with Brand Loyalty Caused by Consumer
} 
not lead the patentee to exploit her full monopoly power, as she would in a world where patents were the only available form of protection. $^{72}$

Assume that the demand for the patented invention is described by a linear (inverse) demand curve,

(1) $P=a-b Q$

where $P$ is the prevailing price, $Q$ is the quantity chosen by the patentee, $a$ is the maximum price the patentee can charge (at $Q=0$ ), and $-b$ is the slope of the demand curve. Assume further that the patentee produces at constant inarginal cost, $c .^{73}$ Simce the patentee is a inonopolist while the patent is in effect, in a smgle period model with patent protection she would maximize her profits, as represented by

(2) $\Pi=(a-b Q) \times Q$.

To accoinphish this, she will choose the quantity, $Q$, that solves

(3) $\partial \Pi / \partial Q=a-2 b Q=0$.

This implies that $Q^{*}$, the profit maximizing quantity for the patentee, is $a / 2 b$. Intuitively, the monopohst sets marginal revenue equal to marginal cost (here, 0 ) in order to maximize profits. Note,

Learning-by-Using, 40 J. Indus. Econ. 397 (1992)-and seems intuitively plausible.

${ }^{72}$ We stress that we are far from the first to point out that a monopolist who considers the long run will have reasons for selling more than (and pricing below) the singleperiod monopoly optimum. For example, Professor Darius Gaskins showed how a forward-looking monopolist would lower prices over time in order to deter entry. Darius W. Gaskins, Jr., Dynamic Limit Pricing: Optimal Pricing under Threat of Entry, 3 J. Econ. Theory 306 (1971). Professor Klemperer's model of switching costs yields the same insight - oligopolistic firms may price at less than the static oligopoly optimum in order to attract loyal users. See Klemperer, supra note 71, at 375-79. Other reasons for pricing below the static monopoly optinium include network externalities and "learning-by-doing" (dynamic scale economies). See Gabszewicz et al., supra note 71 .

Our story is related to the "Coase Conjecture" about the inability of a monopolist producing a durable good to extract monopoly profit over time. See R.H. Coase, Durability and Monopoly, 15 J.L. \& Econ. 143 (1972). Professor Coase's insight was that the monopolist's potential future output may compete with her own present output, so that consumers miglit rationally wait until next year to buy if the price this year is too high. While there are some parallels, the large and complex literature spawned by Coase's insiglit does not bear directly on our model.

${ }^{73}$ Witlout loss of generality, we assume $c$ is equal to zero. 
however, that $Q^{*}$ is only half of the socially optimal output, represented by $a / b{ }^{7}$

Assume, now, that instead of a single period of patent protection, patentees can also take advantage of trademark protection at the expiration of the patent. Demand is the same as in equation (1) in both periods. We now consider how this changes the patentee's behavior during the lifetime of the patent. As we show, the exact effect of trademark protection depends on how the firm's preexpiration sales influence its profitability in the second period once the patent has lapsed.

To start with the simplest case, suppose the patentee cannot take advantage of trademark protection after the patent expires. This might occur if Singer and Kellog are read to ban trademark protection for previously patented products, or if the characteristics of the product make development of brand loyalty impossible. ${ }^{75}$ In this situation, once the product goes off patent, anyone can produce it, and the price will fall to the competitive level. Since the original product is indistinguishable from the version produced by the entrants, the law of one price requires that the previously patented and new versions must sell at the same price. As long as entry is possible, price will be driven down to marginal cost, with zero profit. $^{76}$

If the patentee expects in Period 1 that the market will be competitive in Period 2, she will maximize profits im Period 1 by charging the monopoly price. Since nothing she does in Period 1 affects her profits in Period 2, she faces the monopolist's one-period maximization problem and behaves accordingly." This is the stan-

\footnotetext{
${ }^{74}$ In a competitive market, price equals marginal cost. With marginal cost equal to zero and a linear demand curve, this requires $0=a-b Q$, which implies $Q=a / b$.

${ }^{75}$ We found several instances in which more than one entity has the same name or produces the same product. The best example is the trade name "Bayer Aspirin." When Bayer lost its U.S. plant to an American firm during World War I, it also lost the Bayer name and the company's trademark, the Bayer Cross. As a result, both companies sold Bayer Aspirin. That is, "two different, competing enterprises used an identical name to sell an identical product," and the "two Bayer aspirins fought ench otlier for more than seventy years." Mann \& Plummer, supra note 21, at 15.

${ }^{76}$ This assumes that there are no fixed costs, which we have already factored out of the problem. We are also assuming that product quality is exogenously fixed, so that in the absence of trademark protection, firms would not run-down the quality of their products.

${ }^{n}$ Formally, $\Pi=P_{1} Q_{1}+P_{c} Q_{2}$, where $P_{c}$ is the competitive price. In this case, the sec-
} 
dard account of how patentees behave. ${ }^{78}$ As we will show, however, the conventional view is merely a special case of a more general model, which allows for the patentee to retain soine market power in Period 2 by establishing brand loyalty among her Period- 1 customers. $^{79}$

In a two-period world without brand loyalty, the patentee will act as a monopohist while she can do so (in Period 1). Once we consider brand loyalty made possible by trademark protection, however, it becomes clear that the patentee may prefer not to charge the full monopoly price. We suggest that a patentee who can cultivate brand loyalty while the patent is im effect will prefer to forego some revenues $\mathrm{m}$ the patent period in order to obtain higher profits after the patent lapses. We use the term "trademark leverage" to describe patentees' ability to charge supracompetitive prices even after the patent has lapsed and the invention is protected only by a trademark. ${ }^{80}$

Inherent $\mathrm{m}$ the definition of brand loyalty is the notion of prior use. Indeed, it would be odd for consumers to be loyal to a product they have never tried. Hence, the number of sales made while the patent is in effect will affect the patentee's loyal customer base in Period 2. Critically, this means that mcreasing sales in Period 1 enables patentees to charge supracompetitive prices to more customers in Period 2 than would otherwise be possible.

Formally, we model this effect as a switching cost, so that any consumer who tries the product in Period 1 incurs a cost, $S>0$, to purchase a different brand in Period 2. ${ }^{81}$ The introduction of

ond-period profit is zero, so the patentee does not care what quantity it sells in Period 2, only in Period 1.

${ }^{78}$ See Cooter \& Ulen, supra note 22, at 128.

${ }^{79}$ The existence of trademark makes it possible for consumers to identify the output of each firm, and this might be thought to make each firm less than perfectly competitive with its rivals. Should the behavior in Period 2 then be modeled as monopolistic competition? Jean Tirole suggests not, arguing that "[t]he point of monopolistic competition [theory] is ... not to study strategic aspects between products (such as product positioning and price competition), but rather to abstract from thein to simplify the analysis and study other issues, such as the number of products offered by a market economy." Jean Tirole, The Theory of Industrial Organization 288 (1988).

${ }^{\infty}$ We stress that the existence of "leverage" depends on the characteristics of the product being sold. For a discussion of factors that enhance or limit the development of brand loyalty, see infra text accompanying notes 85-99.

${ }^{81}$ This phenomenon can occur for a number of reasons, many of which can be cap- 
switching costs drives a wedge between the price the patentee can charge her loyal customers and the price new entrants can charge this group. In other words, consumers who buy from the patentee in the first period will be willing to pay a premium of $S$ for the previously patented product, even when identical products are available at a lower cost. Therefore, when the patent expires and entry drives the price down to the competitive level, the price that patentees can charge loyal customers in Period 2, $P_{2}$, is $P_{c}+S$.

The patentee would never find it in her interest to charge less than $P_{c}$ (which would earn negative profit), and if she were to charge more than $P_{c}+S$, she would lose all her customers. Hence, the patentee will always choose the price in Period $2, P_{2}$, to be $P_{c}+$ $S^{82}$

tured under the rubric of "switching costs"-defined as a cost that a consumer must pay to change brands. For example, consumers may learn how to use a product by consuming it. For example, a regular airline traveler who has learned how to find her way around United's terminal may then prefer to fly United rather than American, even if American offered an identical flight at a lower cost. Sheer force of habit, or uncertainty about product quality, may also lead some consumers to continue buying brands they have purchased in the past, even when lower-priced substitutes exist.

There has been a substantial body of work in this vein, largely focusing on the consequences of switching costs for equilibrium in game-theoretic models of oligopolistic markets. The pioneering work that offers a typology of switching costs and a sophisticated analysis of their effects is by Paul Klemperer. See Klemperer, supra note 71.

The work most similar in spirit to ours is that of Professors Gabszewicz, Pepall, and Thisse. Gabszewicz et al., supra note 71. They nodel a two-period game, with a monopolistic incumbent producing a new product in the first period and then facing an oligopolistic rival in the second. Consumers learn about the product by consuning it, and this creates brand loyalty in Period 2 for those who tried the incumbent's product in Period 1. Their main result is similar to ours-the incumbent will expand its customer base in Period 1 by producing more and charging less than the one-period monopoly optimum. This sacrifice of profits in Period 1 is a form of investment in brandloyalty; its return comes because lower prices and more customers today allow the flrm to keep prices above the coinpetitive level for loyal customers toinorrow. Although it does not discuss either trademarks or patents, the paper is important because it demonstrates that our basic insight does not depend on our admittedly extreine assumption that the market is perfectly competitive in the second period (after the patent lapses).

${ }^{82}$ The patentee no longer faces a downward-sloping demand curve once the patent expires. Her loyal customers will purchase exactly the same quantity they bought last period at any price below $P_{c}+S$, and will purchase nothing at all at any price above this level. Hence, there is no price-quantity tradeoff until the patentee's price exceeds the competitive price by more than the switching cost, $S$. 
At price $P_{c}+S$, the patentee will sell the same quantity in the second period as she did in the first. Hence, the patentee's twoperiod optimization problem becomes:

(4) $M a x \Pi=P_{1} Q_{1}+\left(P_{c}+S\right) Q_{1}=\left(a-b Q_{l}\right) Q_{1}+\left(P_{c}+S\right) Q_{1}$, $Q$

where $P_{1}$ is the price charged in the patent period, $P_{c}$ is the price charged by the competitive entrants, and $S$ is the switching cost for the patentee's loyal customers. To find the profit-maximizing output over the two periods, $Q^{*}$, the patentee solves

(5) $\partial \Pi / \partial Q_{1}=a-2 b Q_{1}+S=0$,

which implies

(6) $Q^{* *}=(a+S) / 2 b=Q^{*}+S / 2 b$.

The first thing to note is that the patentee's optimal quantity choice with trademark leverage is the same as its cloice without leverage, plus the positive term $S / 2 b$. Hence, the optimum quantity under a leveraged patent is always larger than witlout leverage $\left(Q^{* \prime}=Q^{*}+S / 2 b>Q^{*}\right)$.

The reason for this result is simple. For a leveraged patentee, an increase in first period quantity has two effects. On the one hand, expanding output above the single-period monopoly level reduces current profits. On the otlier hand, more output today means more loyal customers and higher profits next period, an effect that is made possible by trademark leverage. A firm that takes leverage into account will optimally produce more than one that does not because the leveraged firm's marginal revenue is always larger at any given quantity.

The welfare consequences of patent leverage follow from its effect on Period-1 output. The more the patentee produces in Period 1 , the lower the price is, and the smaller the monopolistic distortion or deadweiglit loss. While the patentee charges its loyal customers a higher-tlian-competitive price in Period 2, this has no effect on the quantity demanded because the marginal (inexperienced) purcliasers can buy at the competitive price in this period. No efficiency consequences result froin those wlo do buy from the former patentee in Period 2 paying more than the competitive price, since the marginal buyers pay the appropriate price and everyone who 
values the product more than its cost is able to buy it. Of course, the higher price paid by loyal buyers generates higher profits for the former patentee, but this has purely distributional effects. Higher consumer prices translate directly into higher profits for the patentee, with no quantity reduction and hence no deadweight loss.

Finally, note that the leverage effect is directly proportional to the size of the consumer switching cost, and negatively related to the slope or elasticity of the demand curve. The first relationship should be obvious. Higher switching costs make consumers less likely to switch, while naking the capturing of consumers more valuable. Hence, as $S$ increases, each dollar of lower profit from output expansion in Period 1 is traded off against higher profits in Period 2, which encourages additional production in the first period.

As the slope parameter, $-b$, gets larger and the demand curve gets steeper, the leverage effect becomes weaker. The reason is the converse of the one given above. The more price-sensitive consumer demand is in Period 1, the greater the fall in Period 1 price for any given quantity increase. Hence, inelastic demand imposes on the patentee a larger burden in foregone profits in Period 1 for each additional Period- 2 customer it seeks to retain.

Table 1 provides a numerical illustration of our results using the parameters listed below.

Table 1: Profits and Welfare Over Two Periods, With and Without Trademark Leverage

\begin{tabular}{|c|r|r|r|r|}
\hline & $\begin{array}{c}\text { Patent } \\
\text { Only }\end{array}$ & $\begin{array}{c}\text { Patent }+ \\
\text { Trademark }\end{array}$ & $\begin{array}{c}\text { Absolute } \\
\text { Change }\end{array}$ & $\begin{array}{r}\text { Percent } \\
\text { Change }\end{array}$ \\
\hline Patentee's Profits & 2500.0 & 3025.0 & 525.0 & 21.0 \\
\hline Consumer Surplus & 6250.0 & 5962.5 & -287.5 & -4.6 \\
\hline Total Welfare & 8750.0 & 8987.5 & 237.5 & 2.7 \\
\hline$\%$ of Maximum Welfare & 87.5 & 89.9 & & \\
\hline
\end{tabular}

The Table demonstrates that the addition of even a relatively modest switching cost (equal to one-fifth of the monopoly price)

${ }^{83}$ Calculated based on parameter values: $a=100, b=1, S=10, c=0$. 
can have significant effects: The patentee's profits are $21 \%$ higher, and in spite of this, total static welfare is nearly $3 \%$ higher with leverage than without it. ${ }^{84}$

It is important to stress that the dynamic-or long run-welfare gain from leveraged patents is potentially substantially larger than the static $2.7 \%$ listed $\mathrm{m}$ Table 1 . The reason is that the Table counts as the welfare gain from leverage only the reduction in static deadweight loss (monopohstic quantity distortion) while the patent is in effect. In addition to reducing deadweight loss, however, the ability to leverage patent protection through trademarks and brand loyalty also raises the patentee's profits-in our example, by a hefty $21 \%$. This in turn creates a larger incentive for R\&D expenditures on the part of future patentees, since any innovation is worth $20 \%$ more with leverage than without. Hence, we expect that leverage should give rise to additional innovations that will yield further welfare gains over the long run. The $2.7 \%$ welfare gain should thus be seen as a lower bound.

\section{B. Refinements and Limitations}

The foregoing analysis has implicitly taken the possibility of leverage as a given. We have assumed that customers always exhibit brand loyalty, which patentees can cultivate by lowering prices, regardless of the characteristics of the product or industry. In reality, however, the possibility and magnitude of trademark leverage depend on various factors, such as product characteristics, demandside characteristics, and the existence of intra-brand spillovers.

\section{Product Characteristics}

The econormics hiterature draws a distinction between search and experience characteristics of products. ${ }^{\$ 5}$ Search characteristics are

${ }^{84}$ The explanation for this result is that leverage creates three effects:

1. The patentee increases Period-1 output, which lowers her profits and raises consumer welfare. Consumers gain more than the patentec loses, however, owing to the reduction in deadweight loss;

2. Loyal customers pay more in Period 2 than they otherwise would; and

3. This raises monopoly profit (by more than it fell in Period 1), but does not create any deadweight loss because it represents a pure transfer from consumers to the (former) patentee.

${ }^{s}$ See Nelson, Advertising as Information, supra note 46, at 730. 
those "that the consumer can determine by inspection prior to purchase of the brand. ${ }^{86}$ Experience characteristics are those that can only be ascertained by actual consumption of the product. ${ }^{87}$ A1though it is convenient to speak of search or experience goods, in reahity virtually all goods exhibit a mixture of search and experience characteristics. Consider clothes, typically considered a search good, for example. Even though consumers can observe the design and color of clothing without purchasing it, there are still important attributes that may only be learned through long-term use, including durability, comfort, and compatibility with other clothes. Once such factors are taken into account, it beconies clear that there are very few, if any, pure search goods.

Brand loyalty is easier to cultivate for heterogeneous products with important experience characteristics. Heterogeneous products allow consumers to have preferences across different brands along one or more dimensions. In the context of cars, for exainple, these might include status, safety, gas mileage, and service. The more heterogeneous the product, the greater the potential for brand loyalty. In addition, if such characteristics must be experienced to be appreciated, consumers will be less willing to switch brands once they have found one they like. ${ }^{88}$ Even for goods whose characteristics can be evaluated without actually purchasing them, higher search costs should also promote brand loyalty. Thus, more complex products with important experience characteristics should be more amenable to the exercise of leverage.

\section{Demand-Side Characteristics}

In addition to product attributes, brand loyalty may also be affected by the attributes of the consumers who purchase the product. For example, elderly consumers are likely to be nore brand

${ }^{86} \mathrm{Id}$.

${ }^{87} \mathrm{Id}$.

${ }^{88}$ Certain drugs are an apparent exception: Some consumers will pay substantially more for branded Advil or Tylenol, even though generic ibuprofen or acetaminophen are, by law, chemically identical. The premium commanded by Iayer Aspirin long after the identical product was available from competitors at dramatically lower prices is another example of the same phenomenon. Presumably, producers have succceded in creating artificial distinctions in the mind of consumers even though the underlying physical products themselves are not appreciably different. 
loyal to products such as pharmaceuticals out of fear that alternate drugs will not work as well. ${ }^{59}$ This aversion to trying new drugs is reasonable as long as elderly consumers are satisfied with their current medicines, since experimentation with new ones subjects them to soine risk of harm. Moreover, switching to new products, even superior ones, is less valuable for elderly consumers because the cost of searching will be amortized over a smaller number of remaining purchases. Conversely, teenagers' consumption patterns are strongly affected by social pressures to conform with what peers are buying, and thus they exhibit more brand loyalty.

Another source of brand loyalty is the degree to which consumers fail to take their own future consumption into account when making present consumption choices. Searching for an alternative product is more attractive if a superior product, once discovered, will be purchased repeatedly, simply because the gains per purchase are multiplied by a larger number of purchases. If consumers ignore the fact that they will purchase the product repeatedly, they will thus be more likely to stick with their current choice rather than search for an alternative product.

Brand loyalty is also plausibly influenced by consumers' tastes for variety. Consumers who prefer variety will be predisposed to switch among brands in order to enrich their consumption experience. By contrast, if consumer preferences are subject to habit formation, so that repeated consumption alters the consumer's underlying utility function in favor of the product consumed, brand loyalty will be correspondingly enhanced.

Many prescription drugs are covered by health insurance, and are often provided by HMOs. These institutions are unlikely to develop the same kind of loyalty to a branded drug that individuals have, and instead are likely to make decisions about which drugs to cover based largely on price. When a generic version of Prozac be-

\footnotetext{
${ }^{⿰}$ See James L. Dettore et al., Branding Lessons from Consumer Marketing, Pharmaceutical Executive, May 1, 2001, at 48 ("Loyalty is an extremely important part of pharmaceutical branding. Consumers who have used a medication for a long time often balk when their insurance companies no longer cover that brand. They go to great lengths to get their favorite products, such as calling or writing letters to insurance companies and doctors. Brand loyalty benefits are long term. Consumers fill certain prescriptions continually for years-sometimes for their entire lives.").

${ }^{90}$ See Eric A. Posner, Law and the Emotions, 89 Geo. L.J. 1977, 1986-88 (2001) (discussing, generally, the consumption of "emotion-relevant" goods).
} 
comes available, for example, one would expect many HMOs not to cover Prozac itself, and pay only for its generic substitute. This may have the effect of reducing brand loyalty in the market for prescription drugs, although our story would presumably still apply in other markets (such as over-the-counter drugs). Moreover, HMOs may respond both to marketing efforts by producers and to consumer demand for branded products; their decisions may be governed by soine degree of brand loyalty after all.

\section{Rate of Technological Change}

Another factor that affects the degree of trademark leverage is the rate of technological innovation. For trademark leverage to be valuable for patentees, the patented product must reinain of commercial value at the end of the patent life. The rate of innovation therefore sets a ceiling on the value of patent protection, since subsequent technology inay render a prior innovation obsolete even before its patent expires. For example, the advent of DVD technology might make a patent on a VCR valueless before significant brand loyalty has a chance to develop. ${ }^{.1}$

In an empirical study, Mark Schankerman found that the rate at which patents depreciate varies by industry. ${ }^{92}$ For example, pharmaceutical and chemical patents were estimated to depreciate at a rate of $5 \%$ per year, whereas mechanical and electronic patents depreciated more rapidly, at a rate of $10-15 \%$ per year. ${ }^{93}$ This suggests that the value of trademark leverage will be higher for certain patentees than for others. The slower the rate of patent depreciation, the easier it is to establish brand loyalty.

\section{Spillovers and Brand Equity}

Under most branding regimes, ${ }^{94}$ brand loyalty may spill over across products because customers may generalize from one prod-

\footnotetext{
${ }^{91}$ This statement should be qualified given the analysis of spillovers across products. See infra Section II.B.4.

${ }^{92}$ See Mark Schankerman, How Valuable is Patent Protection? Estimates by Technology Field, 29 RAND J. Econ. 77 (1998).

${ }^{93}$ Id. at 92.

${ }^{24}$ There are many branding structure alternatives. A leading malrketing textbook hists four:

1. Individual brand names: General Mills, for example, produces each product
} 
uct to another made by the same firm. For example, if a consumer has a positive experience with her first type of Kellogg cereal or Ford car, she may be more likely to try a second product made by the same manufacturer. If both of a firm's brands are protected by patents, then intra-brand spillovers should make hittle difference to pricing and quantity decisions. But suppose that product $A$ is patented, while product $B$ is protected ouly by a trademark. In this case, consumers who purchase product $A$ may be induced to buy product $B$ as well. This, in turn, mcreases the patentee's incentive to lower the price of product $A$. A cut in the price of product $A$ will not only mcrease demand for that product, but will indirectly raise demand for product $B$ as well, as consumers transfer their favorable experiences with $A$ to other goods made by the same firm. ${ }^{95}$

Therefore, spillovers across products of the same firm or brand are likely to further the importance of trademark leverage, just as spillovers of brand loyalty across pre- and post-expiration demand for the same product do. ${ }^{96}$ One can thus think of cross-product spillovers as the cross-sectional analog to time-series brand loyalty, with essentially the same consequences-firms will be led to lower prices on monopohistic (patented) goods in order to mcrease demand for competitive (unpatented) goods in the same family of brands.

(Bisquick and Betty Crocker) under a separate label.

2. Blanket family name for all products: a strategy followed by, for example, General Electric.

3. Separate family names for all products: a strategy followed by, for example, Sears (Kenmore appliances, Craftsman tools, etc.).

4. Company trade name plus individual product name: examples include Ford (Ford Taurus, Ford Escort), or Kellogg (Kellogg's Rice Krispies, Kellogg's Corn Flakes).

See Philip Kotler, Marketing Management: Analysis, Planning, Implementation, and Control 450 (9th ed. 1997).

${ }^{95}$ Products $A$ and $B$ are thus technically economic complements, since $d Q_{A} / d P_{\Omega}<0$. The rationale here lias nothing to do with the standard story arising from utility maximization subject to a budget constraint, however. Instead, operating in the background, there is uncertainty about product quality, in the face of which consumers rely on the firm's name to draw inferences about the quality of prospective purchases.

${ }^{96}$ Of course, the decision about which brand naning strategy to adopt is not exogenous. A company that makes fertilizer and pancake mix will be more likely to follow the first strategy rather than second or fourth, precisely to avoid "contaminating" one of its brand names with associations from the other. 
While a complete theory of brand loyalty is well beyond the scope of this paper, Table 2 provides a summary of some of the relevant factors that determine the extent to which consumers will persistently buy the same brand, even when similar alternatives sell for less.

Table 2: Factors Promoting or Retarding Brand Loyalty

\begin{tabular}{|c|c|}
\hline $\begin{array}{c}\text { Market or Product } \\
\text { Characteristic }\end{array}$ & Effect on Brand Loyalty \\
\hline $\begin{array}{c}\text { Homogeneous or } \\
\text { Simple Product }\end{array}$ & $\begin{array}{c}\text { Little rationale for brand loyalty if all products are } \\
\text { similar-for example, nails, gasoline, paper. }\end{array}$ \\
\hline $\begin{array}{c}\text { "Search" Attributes } \\
\text { Important }\end{array}$ & $\begin{array}{c}\text { Products whose key attributes are well-described } \\
\text { prior to purchase are easy to compare; consumers } \\
\text { should be willing to switch to another brand if specifica- } \\
\text { tions (or price) are superior to usual choice." }\end{array}$ \\
\hline $\begin{array}{c}\text { Information Costs } \\
\text { Habit-Forming } \\
\text { Product }\end{array}$ & $\begin{array}{l}\text { Consumers have more or better information about } \\
\text { tion about rival products (for example, via Consumer } \\
\text { Reports) yields less loyalty. }\end{array}$ \\
\hline $\begin{array}{c}\text { Products that change tastes of consumers generate } \\
\text { higher brand loyalty. }\end{array}$ \\
Relative to Search Cost \\
$\begin{array}{c}\text { Product Appeals to } \\
\text { Especially Habit-Prone } \\
\text { Customers }\end{array}$ & $\begin{array}{c}\text { Consumers do not find it worthwhile to sample } \\
\text { cause little price or utility gain-for example, tooth- } \\
\text { paste. }\end{array}$ \\
\hline $\begin{array}{c}\text { Particular types of products-for example, life in- } \\
\text { surance (for the risk-averse) and arthritis medicine (for } \\
\text { the elderly), increase brand loyalty. }\end{array}$ \\
\hline $\begin{array}{c}\text { Frequent Purchase }+ \\
\text { Consumer Myopia }\end{array}$ & $\begin{array}{c}\text { If one-time switching cost amortized over large } \\
\text { number of future purchases, consumers should be will- } \\
\text { ing to switch brands even if price difference is small } \\
\text { relative to the switching cost." }\end{array}$ \\
\hline
\end{tabular}

\footnotetext{
${ }^{97}$ Nelson, Advertising as Information, supra note 46 , at 730 .

${ }^{98}$ Nickolay Moshkin \& Ron Shachar, Switching Costs or Search Costs? 3 (Jan. 13, 2000) (unpublished working paper, Tel Aviv University) (on file with the Virginia Law Review Association).

${ }^{99}$ See infra Appendix.
} 


\section{EMPIRICAL EVIDENCE OF SYNERGIES}

While the relationship among patents, trademark protection, and brand loyalty is-we believe-an original contribution of this Article, a number of empirical studies support or are consistent with our model. We briefly discuss the prior academic literature, and then document several case studies in which firms liave developed synergies between patents and trademarks in much the way our theory predicts.

\section{A. Previous Empirical Work}

There is a substantial einpirical literature documenting the existence of brand loyalty. ${ }^{100}$ For example, a recent study by Andrea Coscelli finds loyalty is prevalent among consumers, even for drug brands that, by law, are chemically identical, and even after controlling for the prescribing behavior of physicians. ${ }^{107}$ Professors Greg Allenby and Peter Lenk also find persistence in buying patterns over time, using supermarket scanner data on a variety of consumer purchases. ${ }^{102}$ Although their focus is on sellers' price and cost margins rather than on consumer belıavior per se, Professors Barsky, Bergen, Dutta, and Levy uncover large price premia for name brands over essentially identical house brands across a wide range of consumer products-a finding consistent with the importance of brand loyalty. ${ }^{103}$

\footnotetext{
${ }^{100}$ See, e.g., Kotler, supra note 94, at 444 (describing the importance of brand loyalty for marketimg management).

${ }^{101}$ Andrea Coscelli, The Importance of Doctors' and Patients' Preferences in the Prescription Decision, 48 J. Indus. Econ. 349, 367-68 (2000).

${ }^{102}$ Greg M. Allenby \& Peter J. Lenk, Reassessing Brand Loyalty, Price Sensitivity, and Merchandising Effects on Consumer Brand Choice, 13 J. Bus. \& Econ. Stat. 281 (1995).

${ }^{103}$ See Robert Barsky et al., What Can the Price Gap Between Branded and Private Label Products Tell Us About Markups? (Nat'l Bureau of Econ. Research, Working Paper No. 8426, 2001). Since the authors do not track individual consumers' purchases over time, their work does not actually demonstrate brand loyalty. But without such loyalty, it would hard to understand how, for example, Advil or Motrin could sell for substantially more than the house brand of ibuprofen, which is chemically identical. This study is notable for its scrupulous care in eliminating product types for which the house brand might be of lower physical quality than the name brand, such as toilet tissue and soft drinks. Id. at 12-16. Professors Raj Sethuraman and Catherine Cole use survey data to demonstrate that many consumers have strong preferences for national over house brands, even when they acknowledge that the higher prices charged
} 
Beyond the existence of brand loyalty, there are scattered references in the empirical literature to synergies between loyalty and patents. For instance, writmg in 1980, Professor F.M. Scherer, author of the leading textbook in Industrial Organization, noted:

Competition, product differentiation, and natural lags interact to form... imcentives for investment in research and innovation. Frequently, a company's image is enhanced by being first on the market with a new product, and through this product differentiation advantage it may be able to maintain a favorable price differential or retain a sufficiently large share of the market to earn supranormal profits for some time .... ${ }^{104}$

Similar conclusions were reached by Professor Levin and others in a study of the factors that allow firms to appropriate the benefits of innovations. ${ }^{105}$ Using survey data from interviews with high-level R\&D executives, these authors conclude that in many industries, patents are relatively unimportant in protecting firms' R\&D expenditures, in part because "investinents to establish the brand naine of a patented product inay outhve the patent itself.",106

After surveying the einpirical literature on the causes and consequences of being the first firm to enter a market, Professors Robinson, Kalyanaram, and Urban conclude that "[f]irst-mover advantages ... are important $\mathrm{m}$... [several] industries. The sources of these first-mover advantages are varied, but customer familiarity and brand loyalty are important. Overall, a market pioneer's en-

by the former do not reflect quality differences. See Raj Sethuraman \& Catherine Cole, Why do Consumers Pay More for National Brands than for Store Brands? 35 (Mktg. Science Inst., Report 97-126, 1997).

${ }^{104}$ F.M. Scherer, Industrial Market Structure and Economic Performance 445 (2d ed. 1980). Only one study was offered as evidence for this proposition, id. at $445 \mathrm{n} .25$, however. See Ronald Bond \& David Lean, Fed. Trade Comm'n, Sales, Promotion, and Product Differentiation in Two Prescription Drug Markets 11-79 (Staff Report, Feb. 1977). Moreover, neither study draws the connection between trademarks and brand loyalty.

${ }_{105}$ Richard C. Levin et al., Appropriating the Returns from Industrial Research and Development, 3 Brookings Papers on Econ. Activity 783 (1987).

${ }^{106}$ Id. at 784. While downplaying the importance of patents generally, the study by Levin and his colleagues concludes that patents are crucial to protecting intellectual property in some industries (for example, the drug and chemical industries). And where trade secrets, rather than patents, are the ineans of protection, our analysis remains valid. See discussion infra Section IV.A. 
during trademark protection is more important than patent protection."

Moreover, they note:

[F]irst-1nover advantages developed in the marketplace are typically more general and long-lasting than product patent protection .... [In addition,] the empirical results indicate that trademark protection of the pioneer's brand name is often important. When consumers rely on the known and familiar pioneering name, gaining trial can be especially difficult for later entrants. Strong brand names are often maintained for literally generations. For example, 19 of the top 25 consumer brand names in 1923 were still market leaders in $1983 .^{106}$

In sum, the academic literature offers support for our view that brand loyalty is an important phenomenon and that it can be used in combimation with patent protection to generate supracompetitive rates of return to firms with new products.

\section{B. Case Studies}

In this Section, we offer several examples of how patented products are marketed with an eye towards the expiration of the patent. In each instance, the patentees have adopted a strategy of building market share and brand loyalty for the period after the patent expires. Although the examples do not offer full sets of time-series data on pricing and output decisions, patentees do seem to be cutting prices and increasing output, and for precisely the reasons predicted by our model.

\section{Roundup}

One of the clearest examples of using a brand name to leverage one's patent protection is Roundup (cheimical naine, glyphosate), an herbicide patented by Monsanto in $1980 .{ }^{109}$ "Roundup is the best-selling agricultural chemical product ever, with $\$ 2.8$ billion of

\footnotetext{
${ }^{107}$ William T. Robinson et al., First-Mover Advantages from Pioneering New Markets: A Survey of Empirical Evidence, 9 Rev. Indus. Org. 1, 6 (1994).

${ }^{100}$ Id. at $17-18$.

${ }^{109}$ See Robert Steyer, Monsanto Reports Success for New Roundup, St. Louis PostDispatch, Dec. 22, 1996, at 1E.
} 
sales [in 2000]; it outsells other chemicals five to one." ${ }^{\prime 10}$ Despite the monopoly conferred by its patent, Monsanto began cutting prices on Roundup in the mid-1980s, in order to develop an additional customer base. ${ }^{111}$ The company followed-

[a] brilliant strategy of dropping its price years ahead of patent expiration .... "It was a classic pricing strategy," .. "a textbook case. Every 1 percent price drop led to a 2.5 or 3 percent increase in volune."... Even more, few coinpetitors are willing to produce a generic version of Roundup ... because Monsanto has protected its inarket dominance by cutting the price while finding new uses. This built loyalty while reducing the profit that potential competitors could reap by trying to lure away customers. ${ }^{112}$

The company continued to drop prices as the date of the patent expiration neared. ${ }^{113}$

\section{NutraSweet}

Patented by Searle in 1972, the artificial sweetener aspartame was not introduced on the market until ten years later under the brand naine NutraSweet. ${ }^{114}$ From the beginning, the conipany apparently focused on building brand loyalty for the period after the

${ }^{110}$ David Barboza, The Power of Roundup, N.Y. Times, Aug. 2, 2001, at C1.

${ }^{111}$ Steyer, supra note 109 , at $1 \mathrm{E}$.

${ }^{112}$ Barboza, supra note 110 , at C1, C6.

${ }^{113}$ The retail price of Roundup fell from "about $\$ 44$ a gallon in 1997 to $\$ 34$ in 1999 to about $\$ 28$ [in 2000]." Id. at C6.

As both of the previous articles make clear, the company also adopted numerous other tactics to forestall competition besides cutting prices to build brand loyalty. For example, Monsanto made technical modifications to the chemical in response to consumer demand, and in an attempt to receive a new patent. The company also built substantial production capacity in advance of demand in order to forestall entry by competitors. And it agreed to license its product to competitors once the patent expired, making it unattractive for competitors to produce glyphosate themselves. Finally, Monsanto created crops that were genetically-engineered to be tolerant to Roundup, so that the herbicide could be sprayed directly on the fields, killing weeds but not the crops. Consumers who used Monsanto's genetically-modified ("RoundupReady") seeds had to sign an agreement promising to use only Monsanto's herbicides rather than generic glyphosate. See Steyer, supra note 109, at 1E.

${ }^{114}$ Nancy Milman, King of the Tabletop: NutraSweet Pours on Loyalty Effort, Chi. Trib., Sept. 17, 1995, at 2. 
patent expired. Initially, NutraSweet was available only to producers, not to the public at all, and sold for $\$ 90$ per pound. ${ }^{\text {is }}$

In 1984, as Coca-Cola Co. and PepsiCo were reformulating their newly burgeoning diet colas from saccharin blends to aspartame sweetener, the NutraSweet company used its growing consumer loyalty base to negotiate more exposure for its brand. NutraSweet cut the sweetener's price to companies that featured the new "100 percent NutraSweet" trademark swirl on their packages, and bestowed even bigger breaks for ad campaigns mentioning the reformulation. ${ }^{116}$

As the date of the patent's expiration neared, NutraSweet "started dropping its prices.... In 1989, prices were cut by 3 percent, and another 6 percent was lopped off in 1990 .... In 1991, ... the company cut prices by 10 percent, and it did so again in $1992 \ldots$. The next year prices dropped by another 25 percent .....117

\section{Tagamet}

In 1993, SmithKline Beecham announced a direct-to-the-customer rebate of $\$ 10$ per month on the ulcer medication Tagamet, for a $\$ 20$ per month savings over archrival Zantac. ${ }^{118}$ This was apparently the first time that price cuts or rebates to consumers had ever been used to bolster sales of a prescription drug. ${ }^{119}$ Analysts linked the price drop to the fact that Tagamet was going off-patent in May of 1994, and the desire to build brand loyalty before the advent of generic competition. ${ }^{120}$

\section{Zovirax}

An antiviral cream made for cold sores, Zovirax was initially available only by prescription. In 1992, its manufacturer, BurroughsWellcoine, attempted to get approval for over-the-counter sales (at a substantially lower price) because the patent was due to expire in

\footnotetext{
${ }^{115} \mathrm{Id}$.

${ }^{116} \mathrm{Id}$.

${ }^{117} \mathrm{Id}$.

${ }^{118}$ Milt Freudenheim, A Drug Promotion Based on Price Breaks the Prescription Tradition, N.Y. Times, Nov. 9, 1993, at A1.

${ }^{119}$ See id. at D2.

${ }^{120}$ See id.
} 
1995. ${ }^{121}$ "Switching to selling over the counter is one of the strategies Wellcome is using to protect its revenue from Zovirax. It hopes to be able to build brand-loyalty among consumers, so enabling it to maintain sales when its patent runs out and competitors come in to the market."122

\section{Bayer Aspirin}

According to Mann and Plummer's careful history of Aspirin, the originator of the drug-Germany's Bayer Co.-explicitly took steps to leverage its patent protection through trademark after the patent expired. ${ }^{123}$

To counter the loss of its [American] patent, the firm turned to its trademark. Bayer would try to make consumers so thoroughly identify headache and fever relief with Bayer Aspirin that its rivals would have no chance .... [Bayer decided] to boost the U.S. production of Aspirin in tablet form. Each tablet was stamped with the Bayer Cross, [the company's trademark,] and the tablets were put in Bayer packages, which for the first time let consumers see the name of the company that cured their headaches. ${ }^{124}$

Again, we see a famihar story of trademark leverage-an attempt to extend patent protection by means of trademark and brand loyalty, and an expansion of output while the product is still under patent in order to increase the number of loyal customers.

What these cases show is that, especially near the end of a patent's life (but sometimes much earlier) some firms do implement a

${ }^{121}$ See Heather Connon, Pharmaceutical and Medical Sales: Companies Keen to Switch, The Independent (London), July 22, 1992, at 14.

${ }^{122} \mathrm{Id}$.

${ }^{123}$ Mann \& Plummer, supra note 21, at 37.

${ }^{124}$ Id. The reaction of the American Medical Association to this effort was strongly negative. An editorial in the Association's Journal echoed the insular view of intellectual property often expressed today, noting that-

[f]or seventeen years, ... it has been impossible in this country for anybody except the Bayer Company to manufacture or sell acetylsalicylic acid .... Needless to say, the American people have been made to pay exorbitantly for the monopoly our patent office granted this firm .... Not content with the ironbound monopoly which it had been granted through our patent laws, the company attempted further to clinch its exclusive rights by giving the preparation a fancy name, "aspirin," and getting a trademark on this name.

Id. at 38 (quoting JAMA, Jan. 20,1917, at 201-02.). 
strategy precisely like the one predicted in our model. In an effort to survive after the expiration of the patent makes generic competition inevitable, firms increase output and cut prices. (Of course, many other tactics are often pursued simultaneously as well.) This is described as an effort to build brand loyalty-an attempt to make the product distinctively attractive to consumers who will soon be faced with a cheaper generic alternative. What is not stressed in the reports on which these case studies are based is that the effort to develop and maintain brand loyalty also serves to increase overall efficiency.

\section{EXTENDING THE ANALYSIS TO TRADE SECRECY AND COPYRIGHT}

In this Part, we examine the applicability of our findings to trade secrecy and copyright protection. We posit that despite the fundamental differences between trade secrecy and patents, the combination of trade secrecy and trademark protection generates the same efficiency effects we identified with respect to patents in cases in which trade secrecy creates market monopolies. In fact, the uncertain, or probabilistic, nature of trade secrecy-the fact that trade secrets may becoine public at any time-implies that the positive impact of trademarks in this context may be greater than in the context of patents.

We also predict that combining copyright with trademark yields much smaller efficiency effects relative to those we identified for patents and trade secrets. This difference is predominantly due to the fact that copyright protection is long enough to inake the possibility of additional tradeinark protection in the post-copyright period of very limited value for copyright owners. Thus, we expect the availability of trademark protection to have an inconsequential effect on the pricing decisions of copyright owners.

\section{A. Trade Secrecy}

Originating in the middle of the nineteenth century, ${ }^{125}$ trade secret law protects any information that derives independent eco-

${ }^{125}$ See Robert G. Bone, A New Look at Trade Secret Law: Doctrine in Search of Justification, 86 Cal. L. Rev.241, 247 (1998) (discussing the origin of trade secret law). 
nomic value from being disclosed when that information is subject to reasonable secrecy precautions. ${ }^{126}$ In principle, trade secret law applies to unpatentable as well as patentable information. ${ }^{27}$ Consequently, trade secrecy serves both as a complement to and substitute for patent protection. As a complement to patent law, trade secret law protects information that fails to meet the patentability standard for lack of novelty, usefulness, or nonobviousness. ${ }^{128}$ As a substitute for patent protection, trade secrecy presents businesses with a choice between patent and trade secret protection. While firms can elect either option, they cannot employ both modes to protect the same information. The subject matter overlap is evident in trade secret hitigation. As one commentator reported, most trade secret cases "involve technological subject matter-such as the formula for Coca-Cola, a process for making methanol, or the dimensions of a robot-operated machine."129

Notwithstanding the extensive subject matter overlap, patent and trade secret protection differ in three important respects. First, patent protection is conditioned on full disclosure; trade secrecy rests on non-disclosure. In the context of patent, it is the disclosure of valuable information that justifies the social cost associated with the legal monopoly. ${ }^{130}$ In contrast, secrecy is the touchstone of trade secret law.

${ }^{126}$ Section 1(4) of the Uniform Trade Secrets Act, adopted with some minor changes by over forty-three states, defines "trade secret" as:

information, including a formula, pattern, compilation, program, device, method, technique, or process, that: (i) derives independent economic value, actual or potential, from not being generally known to, and not being readily ascertainable by proper means by, other persons who can obtain economic value from its disclosure or use, and (ii) is the subject of efforts that are reasonable under the circumstances to maintain its secrecy.

Unif. Trade Secrets Act $\S 1$ (4) (amended 1985).

${ }^{127}$ See 2 Roger M. Milgrim, Milgrim on Trade Secrets $\$ 8.02[5]$ (2002); see also Bone, supra note 125 , at 248 ("[A]lmost anything can qualify as a trade secret, pro. vided it has the potential to generate commercial value.").

${ }^{123}$ Id. ("Unlike patent law, which only protects inventions that are 'nonobvious,' trade secret law protects all inventions that confer a competitive advantage, even ones that are not especially new.").

${ }^{129}$ Id.

${ }^{130}$ This foundational exchange-the grant of a temporary monopoly in exchange for adequate disclosure-is a long-standing principal of patent law. See, e.g., Grant v. Raymond, 31 U.S. (6 Pet.) 218, 247 (1832) (noting that an enabling disclosure "is necessary in order to give the public, after the privilege shall expire, the advantage for which the privilege is allowed, and is the foundation of the power to issue the pat- 
Second, the protection bestowed by patent law is significantly stronger than that conferred by trade secret law. Patent protection bars others from manufacturing, using, selling, and importing the invention while it is patented. In fact, the protection is so broad that even if a competitor arrives at the patented invention independently and attempts to market it, she will still be liable for infringement; independent development does not shelter one against an infringement suit. ${ }^{131}$ The protection accorded by trade secret law, im contrast, is much more limited. Trade secret law protects the information holder only against improper appropriation by others. Liability under trade secret law requires a showing of "breach of contract, violation of a confidential relationship, theft, bribery, misrepresentation, and other wrongs." does not prohibit copying of pubhcly available products, ${ }^{133}$ nor does it forbid reverse-engineering.

Third, trade secret protection has no built-in time limit. Unlike patent protection, which endures for a uniform period of twenty years, trade secret protection lasts as long as a reasonable effort is inade to keep the information secret, and no competitor succeeds in appropriating the information by legitimate means-usually by reverse-engineering. Thus, in principle, trade secrecy may last in perpetuity.

On first impression, the potentially infinite duration of trade secret protection seems to suggest that trademark protection is useless for trade secret holders. A closer examination, however, reveals that this conclusion is unwarranted. By its very nature, trade secret protection is uncertain. Competitors of the trade secret holder may, at any time, successfully overcoine the secrecy legitimately and appropriate the protected information. Alternatively, they may

ent"); Edmund W. Kitch, The Nature and Function of the Patent System, 20 J.L. \& Econ. 265 (1977) (suggesting that an important aspect of patents is their influence, through disclosure of new technologies, on future R\&D, not their impact on ex ante incentives to innovate).

${ }^{131}$ See, e.g., Kewanee Oil Co. v. Bicron Corp., 416 U.S. 470,478 (1974) (holding that unknowing and unintentional duplication of a patented invention is still infringement).

${ }^{132}$ See Bone, supra note 125 , at 250.

${ }^{133}$ See Restatenient (Third) of Unfair Competition $\$ 43$ (1995); Unif. Trade Secrets Act $\S 1(4)(i)(1985)$.

See id. 
arrive at the protected information independently. In other words, the successful continuation of trade secrecy is probabilistic. The protection may last forever, or end at any given moment. Table 3 gives the expected life of a trade secret, given various annual probabilities that the secret will be discovered. ${ }^{135}$ For an annual probability of detection of $25 \%$, the trade secret's expected life is twelve years, rising to twenty-seven years for an annual detection rate of $17.5 \%$.

Table 3: Expected Life of a Trade Secret, for Various Annual Probabilities of "Discovery" by Rivals

\begin{tabular}{|c|r|r|r|r|r|}
\hline Annual Probability of Discovery & 0.75 & 0.50 & 0.25 & 0.20 & 0.1 \\
\hline Expected Life, in Years & 0.44 & 2.00 & 12.0 & 20.0 & 90.0 \\
\hline
\end{tabular}

For our purposes, this fact inakes trade secrecy closely analogous to patent protection, at least for secrets that are moderately likely to be discovered. Both patent and trade secret give firms the same advantage: lead-time. In the case of patents the lead-time is certain and limited, while in the case of trade secret protection the leadtime is uncertain and potentially unlimited.

The uncertain nature of trade secrecy creates a two-terun planning horizon for the rational trade secret holder-very much as it did for the rational patentee. The probabilistic event of termination should prompt the trade secret holder to consider not only the trade secrecy period, but also the period that follows, in which trademark is the only available protection. Thus, even in the instances in which trade secrecy bestows a inonopoly position, ${ }^{136}$ a ra-

\footnotetext{
${ }^{135}$ The expected life is given by $\sum_{f=0 t \times}^{\infty}(1-\lambda)^{\prime}$, where $\lambda$ is the constant probability of discovery in any year and $t$ is the number of years since the secret originated.

${ }_{136}$ Because trade secret law protects non-novel information, and bicause the protection accorded by trade secrets is weaker than that conferred by patents, not every instance of trade secret protection raises a monopoly problem. At the same time, trade secrecy also extends to inventions that could, in principle, be patented. In such cases, inventors will choose trade secret over patent protection only if their expected revenues from trade secrecy exceed their expected revenues from patent protection. This will happen when: (1) patent imfringements are difficult to prove (as is sometimes the case with process patents); (2) the patentee lacks the wherewithal to afford litigation; or (3) trade secrecy grants the inventor a monopoly that is expected to last longer than the statutory patent period. Obviously, the latter scenario is the most troubling since it imposes a potentially greater deadweight loss than patent protection, and no
} 
tional trade secret holder should sacrifice some of her monopolistic rents during the secrecy period in order to enhance her brand recognition and preserve higher revenues in the trademark period. As with patent protection, the need to rely on trademark protection in the future curbs the trade secret holder's penchant to price monopolistically.

One important difference between our analysis of patent and trade secrecy protection concerns the timing of the decision to reduce prices. The probabilistic nature of trade secrecy imphes that trade secret holders will lower prices earlier than patentees will. Since patentees are assured twenty years of exclusivity, they will optimally choose to price monopolistically in the early years of the patent, and lower prices only as expiration nears. Trade secret holders face a different calculus.

Assume, for example, that Energy, Inc. holds a trade secret for a cliemical composition used in solar panels. The company estimates that there is a substantial probability that its rivals will learn the formula of its vaunted trade secret in the first few years following its introduction. Under these circumstances, the company will want to utilize trademark protection right away in order to offset the imminent risk of its secret being revealed. The need to rely on trademark protection early in the product's life increases the pressure on trade secret holders to invest in brand loyalty froin the start of the product life cycle, rather than exploiting their market exclusivity in the early years as patent holders do. The earlier timing of the price reduction in the case of trade secret protection thus increases the efficiency gams froin trademark leverage.

\section{B. Copyright}

Copyright protection extends to any original expressive work fixed in a tangible inedium of expression. Like patent protection, copyright protection is limited in tine. The first federal Copyright Act of 1790 limited the statutory subject matter to books, maps, and charts. ${ }^{137}$ Througli time, the subject matter of copyright law has dramatically expanded, and it presently includes musical works,

disclosure is made to the public.

${ }^{17}$ See Joyce et al., supra note 6, at 20.

${ }^{138} 17$ U.S.C. $\$ 102(a)(2)(2000)$. 
sculptural works, ${ }^{139}$ audiovisual works, ${ }^{140}$ architectural works, ${ }^{141}$ designs, ${ }^{142}$ and computer software. ${ }^{143}$

The expansion of copyrightable subject matter has not only engendered a degree of subject matter overlap between copyright and patent law, but has also increased the importance of trademark protection for copyright holders. Like patentees and trade secret holders, copyright holders can rely on trademark protection to maintam a proprietary interest in their works even after the copyright protection expires. Thus, it is not surprising that Disney trademarked many of its famous animated characters in addition to copyrighting them. ${ }^{144}$ Similarly, Microsoft can combine copyright and trademark in protecting its software, and the Italian designer Alessi can employ the same combination to protect his innovative designs.

${ }^{139} \mathrm{Id} . \S 102(\mathrm{a})(5)$.

${ }^{140}$ Id. $\$ 102(\mathrm{a})(6)$.

${ }^{141} \mathrm{Id}$ \&102(a)(8).

${ }^{142}$ Copyrightable designs include statuettes, see Mazer v. Stein, 347 U.S. 201, 217 (1954) (holding that the patentability of the statuettes did not bar them from copyright protection as works of art), and belt buckles, see Kieselstein-Cord v. Accessories by Pearl, 632 F.2d 989, 993-94 (2d Cir. 1980) (concluding that belt buckles are copyrightable because their primary ornamental function is conceptually separable from their subsidiary utilitarian function), but may not include animal nose masks, see Masquerade Novelty, Inc. v. Unique Indus., 912 F.2d 663, 670-71 (3d Cir. 1990) (holding that the artistic element of animal shapes is conceptually inseparable from their utilitarian purpose of creating humor), or inannequins, see Carol Barnhart, Inc. $v$. Econ. Cover Corp., 773 F.2d 411, 418 (2d Cir. 1985) (holding that mannequins are not copyrightable because their the aesthetic and artistic features are inseparable from their use as utilitarian articles).

Besides being protected through the doctrine of conceptual separability, future designs may be protected through sui generis copyright regimes, or through patent or trademark laws. See Joyce et al., supra note 6, at 200-01.

${ }^{143}$ See Sega Enters. v. Accolade, Inc., 977 F.2d 1510, 1521-23 (9th Cir. 1993) (carving out a substantial fair use exception for "reverse-engineering"); Apple Computer v. Formula Int'l, 725 F.2d 521, 523-24 (9th Cir. 1984) (holding that object code is copyrightable); Apple Computer v. Franklin Coinputer, 714 F.2d 1240, 1248 (3d Cir. 1983) (suggesting that computer programs are proper subject matter for copyright protection). Besides being protected by traditional copyright protection, computer software also inay be protected by patent, see Diamond $v$. Diehr, 450 U.S. 175, 187-88, 193 n.15 (1981) (upholding the patentability of an invention related to computer software), or by state trade secret law, state contract law, "shrink-wrap" licensing, or "click-on" licensing. See Joyce et al., supra note 6, at 176-77.

${ }^{144}$ See Jessica Litman, Mickey Mouse Emeritus: Character Protection and the Public Domain, 11 U. Miami Ent. \& Sports L. Rev. 429, 429 (1994). 
How will the trademark leverage affect the pricing decisions of copyright holders? We predict that the combination of copyright and trademark might mitigate the anti-competitive effects of copyright protection in some cases, but we expect the typical efficiency gains to be small. There are several reasons for the difference between patent and copyright leverage. First, trademark protection is virtually irrelevant to most types of copyrighted works, such as paintings, sculptures, and even movies. Once a film falls into the public domain, few consumers will pay more for a copy released by the original studio when identical copies are available on the market for less.

Second, consumers buy most copyrighted work for self-consumption only once; for most copyriglited works, there is no possibility of repeat sales. Once Jane owns a CD of Nirvana's "Nevermind," she can listen to the copyrighted music as much as she likes without buying another copy. The likelihood of Jane purchasing another copy of her favorite novel, James Joyce's "Ulysses," is even lower.

Third, copyriglit protection is so long as to render the additional protection term afforded by trademark law virtually meamingless. The current copyright term is life of author plus seventy years for mdividually created works, and ninety-five years from publication or 120 years from creation (whicliever is shorter) for works made for hire. ${ }^{145}$ As Judge Posner explained, "as a result of discounting to present value..., the knowledge that you may be entitled to a royalty on your book fifty to one hundred years after you publish it is unlikely to affect your beliavior today.,"116 Therefore, before a work is created, the effect of trademark protection on the incentive to create is extremely small.

Moreover, the commercial life span of copyrighted products for whicl trademark protection is relevant is considerably shorter than the copyright term. Consider software: While branding certamly matters for software providers, copyrighted software becomes obsolete years before tlie copyright in the software expires. Thus, fu-

\footnotetext{
${ }^{\text {Is }}$ See 17 U.S.C. $\$ 302$ (2000) (setting out the duration of copyright protection). In the case of "works made for hire," the employer is considered the author of the work and is regarded as the initial owner of the copyright unless the parties have agreed otherwise. See id. $\$ 201$ (b).

${ }^{146}$ Posner, supra note 10 , at $46-47$. At a $5 \%$ annual interest rate, $\$ 1$ in 100 years is worth only $\$ 0.007$-less than a penny-in present value.
} 
ture trademark protection gives software providers no incentive to mcrease sales at present in the hope of making additional sales after the copyright protection ends.

Nonetheless, there may be some instances in which intra-brand spillovers may induce copyright owners to cut prices of copyrighted products in order to increase brand loyalty. Since most copyrighted works are experience goods, the purchasing decisions of consuiners will, to some extent, be influenced by past consunption of other products of the same brand. In hight of this fact, copyright holders may find it in their best interest to reduce prices of popular copyrighted products to attract consumers to try other products of the same brand. For example, Blue Note, the famous jazz label, may rationally reduce the price of copyrighted recordings to entice jazz lovers to purchase the label's other recordings. Likewise, Penguin, the respected publishing house, may not extract the full rent afforded it by copyright protection on its current bestseller in order to convince consumers to buy its edition of "The Dialogues of Plato" and other public domain classics. So, at the margin, concerns for intra-brand spillovers may induce copyright holders to price more competitively. ${ }^{147}$

\section{IMPLICATIONS FOR LAW AND POLICY}

Patent pohicy embodies a tradeoff between dynamic and static efficiency. On the one hand, if innovations can be freely copied, innovators will have no way of appropriating any of the gains they generate, nor of recovering the costs they have incurred in research and development. On the other hand, however, the prices of the innovations would be low, and every consumer who values the product at more than its cost would be able to purchase it.

In the absence of patents, then, there would be essentially no static deadweight loss, but society would incur serious dynainic inefficiencies by eliminating much of the incentive to innovate. This, however, is not the balance society has chosen between dynamic and static efficiency. Instead, we have elected to grant the patentee a limited duration monopoly, allowing her to restrict output and charge monopolistic prices. This enables the patentee to appropri-

\footnotetext{
${ }^{147}$ We discuss spillovers in the patent context. See supra text accompanying notes 94-99.
} 
ate more of the benefits of her innovation, and thereby provides an incentive to invest in R\&D. The downside is that it comes at the cost of static deadweight loss, since invention prices are now set monopolistically, and soine consumers who value the product at inore than its marginal cost are unable to purchase it.

Thus, any level of patent protection imphes a corresponding deadweight loss. Importantly, both the imcentive to innovate and static deadweight loss vary directly with the length of the patent term. Increasing dynamic incentives thus necessarily increases static losses, lience the tradeoff.

As we liave shown, liowever, patents are not the only means for encouraging innovation; trademarks inay complement patents in promoting this goal. The net effect of combimed patent and trade1nark protection is a stronger incentive to innovate than that contemplated by Congress. ${ }^{148}$ The increased protection, inoreover, comes at no cost to society. In fact, it improves social welfare. Our analysis has demonstrated that leveraged patents produce three effects. First, leveraged patents induce patentees to produce more, and price inore competitively than they would under a patent whose effect ends at expiration, as is traditionally assumed. Second, this additional output leads to lower static deadweight losses while the patent is in effect, but higher overall profits for the patentee, and, hence, yields greater ex ante incentives to innovate than a conventional patent. Third, consumers who remain loyal to the patentee's product after the patent expires pay more than they need to, smce they could avail themselves of a competitive product at a lower price. This effect, lowever, is purely redistributive: The consumers' loss is exactly equal to the patentee's gain, with no deadweight loss.

These observations have inportant consequences for innovation policy. They imply, for example, that patents may be shortened, and their attendant deadweight loss reduced, without diminishing the incentive to innovate provided by existing patent protection. Conversely, incentives to innovate may be increased without imposing additional deadweiglit loss on society.

\footnotetext{
${ }^{148}$ A review of the legislative history of Title 35 of the U.S. Code fails to disclose any reference to trademark. Neither the Congress that passed the original Patent Act, nor any subsequent Congress that amended the Act, mentioned the possibility of enhancing the incentive to create through a combination of patent and trademark.
} 
In the remainder of this Part, we analyze the Supreme Court's approach to leveraged patents and demonstrate why the current judicial hostility is misguided. We then explain how legal policy should take advantage of leveraged patents to encourage innovation while reducing deadweight loss.

\section{A. Pitfalls in the Supreme Court's Approach to Leverage}

Driven by strong hostility to the practice, the Supreme Court in Singer Manufacturing Co. v. June Manufacturing Co. ${ }^{149}$ and Kellogg Co. v. National Biscuit Co. ${ }^{150}$ thwarted attempts at leveraging patents through tradeinarks by dramatically diminishing the trademark protection available to patented inventions. ${ }^{151}$ In both cases, the Court ruled that the generic naine by which a patented invention has becoine known falls into the public domain at the expiration of the patent. ${ }^{152}$ In Singer, the Court even permitted competitors to affix the name "Singer" to their sewing machines, thereby coinpletely eliminating the possibility of trademark leverage. ${ }^{133}$ Harkening back to this conception, the Court, in TrafFix Devices $v$. Marketing Displays, held that expiration of a utility patent on a ineclianisin for keeping outdoor signs upright in inclement weather creates a rebuttable presumption that the particular design is ineligible for trade dress protection. ${ }^{154}$

Our analysis demonstrates that the Supreme Cour't's hostility to leveraged patents is ill-conceived. Not only did the Court fail to see the efficiencies generated by leveraged patents, but it also chose the least desirable intervention inethod. By restricting patentees' ability to leverage patents through trademarks, the Supreme Court

${ }^{149} 163$ U.S. 169 (1896).

${ }^{151}$ See supra notes 54-61 and accompanying text. A possible variant on the Supreme Court's approach is to set a time limit on the trademark protection afforded to patentees. Under this approach, the names of previously patented products would be entitled to full trademark protection, but the protection would lapse after a certain pcriod of time, by which point the name would fall into the public domain. While better than the Supreme Court's approach, this solution weakens the value of trademark protection to patentees, and thus, eliminates some of the patentee's incentive to lower prices during the patent's life.

${ }_{152}$ Kellogg, 305 U.S. at 118; Singer, 163 U.S. at 199.

${ }^{153}$ Singer, 163 U.S. at 199-200.

${ }^{154} 532$ U.S. 23,30 (2001). 
has enhanced the incentive for patentees to price monopolistically during the patent life. Any diminution in the scope of trademark protection available to patentees increases the relative value of their patent inonopoly, and, correspondingly, forces them to rely on monopolistic rents to recover their investment in R\&D. Thus, the net effect of the Court's policy is to increase the distortionary effect of patent protection and diminish social welfare.

In fact, the Supreine Court got it exactly backwards-marks that do not designate patented products should be subjected to heightened scrutiny since they do not generate the same leverage effect as marks of patented products. This point leads to a more general insight. In recent years, there has been a spate of criticism of the expansion of tradeinark protection. ${ }^{15 s}$ While we do not seek to justify this expansion generally, we wish to note its beneficial effect in the context of leveraged patents. To the extent that enhanced trademark protection facilitates brand recognition, it is easier for patentees to preserve their loyal customer base, thus increasing the value of each sale inade during the patent term. Tlierefore, the more trademark law protects branding, the stronger the incentive for patentees to reduce prices during the patent's life.

The Court's misunderstanding of leveraged patents has led to a perverse result: While trademark protection generally lias dramatically expanded, the protection afforded to marks of patented products has been set at a minimal level. We subinit that it should go the other way around. Courts should grant stronger trademark protection to marks designating patented innovations than they do to other inarks.

Trade dress protection, however, calls for a more nuanced analysis. ${ }^{156}$ Trade dress protection covers "the appearance or image of goods or services as presented to prospective purchasers." ${ }^{157}$ In analyzing trade dress protection for previously patented products, it is critical to distinguish between the aesthetic design elements and

${ }^{155}$ See Lemley, supra note 13 , at 1688 (suggesting that by protecting trademark owners against uses that would not have been infringements even a few years ago and protecting as trademarks things that would not have received such protection in the past, courts "are well on their way to divorcing trademarks entirely from the goods they are supposed to represent"); see also Glynn S. Lunney, Jr., Trademark Monopolies, 48 Emory L.J. 367 (1999) (attacking expansion of trademark protection).

${ }^{156}$ We are grateful to Mark Lemley for pointing this out to us.

${ }^{15}$ Restatement (Third) of Unfair Competition \$ 16 (1995). 
the functional configurations for which the utility patent was awarded. While we support extending trade dress protection to the aesthetic design elements of patented products, we oppose its extension to patented product configurations. The reason is simple: Whereas protecting aesthetic design elements increases the leverage effect, protecting patented product configurations eliminates leverage altogether. The effect of extending trade dress protection to patented product configurations would be to give patentees perpetual exclusivity over those features. Naturally, under a legal regime in which patents do not expire, patentees would not need to rely on brand loyalty, and consequently, would have no incentive to reduce the price of patented products. ${ }^{\text {iss }}$

\section{B. Relaxing the Tradeoff Between Dynamic and Static Efficiency}

By conferring limited exclusivity upon inventors, patents affect efficiency in two ways: They spur innovation, but generate a deadweight loss. The first effect is positive and dynamic; the second is negative and static. This means that policymakers cannot simply choose the level of patent protection that maximizes the incentive to innovate, nor can they select a level of patent protection that minimizes social deadweight loss. Rather, they must choose a protection level that strikes the right balance between the dynamic efficiency gain and the static efficiency loss. The current protection term-twenty years froin filing-presumably reflects Congress's judgment that any further incentives to innovate would not be worthwhile, given the additional static deadweight loss entailed by an extension of the term.

Conventional theorizing mistakenly assumes that patents exclusively determine the terins-or the "welfare possibility frontier"of the tradeoff between dynamic and static efficiency. On this view,

\footnotetext{
${ }^{158}$ In fact, this is exactly what the respondent, Marketing Displays Inc. ("MDI"), nttempted to do in TrafFix. MDI sought to obtain trade dress protection for its previously patented "dual spring mechanism" used for keeping outdoor signs upright in inclement weather conditions. Denying MDI's request, the Supreme Court ruled that MDI's expired utility patent is strong evidence that the dual spring meehanism is functional, and thus, ineligible for trade dress protection. TrafFix, 532 U.S. at 29-30. Although the Court's analysis was doctrinal, and despite the fact that it relied on the insular view of intellectual property law that we criticized earlier, it renched the correct decision. Our analysis provides an independent, policy-oriented justification for the ruling.
} 
any deviation from the current level of protection is undesirable simce it entails a social cost. Specifically, it is not possible to further enhance dynamic efficiency by mcreasing the mcentive to innovate without also increasing social deadweight loss, nor is it possible to lower social deadweight loss by shortening patents without sinultaneously diminishing the incentive to innovate.

Our analysis of leveraged patents demonstrates that the terms of the tradeoff between dynamic and static efficiency are not as restrictive as previously thought. As we have shown, trademark protection can imcrease the payoff to patentees, and thereby enhance the incentive to innovate, while reducing the deadweight loss generated by patents. By relaxing the tradeoff between static and dynamic efficiency, leveraged patents shift outwards the possibility frontier delineated by patents. Consequently, they create new combinations of incentives to innovate and deadweight loss that are unavailable under discrete patent protection.

For example, the outward shift of the possibihty frontier makes it possible to shorten patent terms without any dynamic efficiency sacrifices. Since leveraged patents have higher profitability than non-leveraged patents, the term of protection for leveraged patents may be shortened without reducing incentives to innovate below those contemplated by Congress for a non-leveraged patent. As long as the drop in profits due to the shorter patent term is lower than (or equal to) the gains from trademark protection, shortening patents would not adversely affect dynamic efficiency; it would at the same time lower the static deadweight loss caused by patent protection.

Conversely, leveraged patents enable pohicymakers to improve dynamic efficiency while maintaining static deadweight loss at the level of ordinary patents. Given that the static deadweight loss of leveraged patents is smaller than that of non-leveraged ones, pohcymakers might wish to increase the protection term for leveraged patents. Since society is willing to put up with deadweight loss of non-leveraged patents, the duration of leveraged patents may be extended until the corresponding deadweight loss equals that of non-leveraged patents. Extending the duration would mcrease the expected return on innovation, and thereby spur greater investment in $R \& D$. 
Figure 1 illustrates the argument graphically. It shows that for a standard patent (no leverage) there is a tradeoff between patentee profits (incentives to imnovate) and static deadweight loss. To give the patentee higher profits, we have to lengthen the patent term, which imcreases the duration of the patentee's monopoly power and attendant distortionary pricing.

As previously discussed, however, the existence of leveraged patents pushes out the "welfare possibility frontier," making possible a range of new alternatives, all of which offer both larger incentives to innovate and smaller deadweight loss than a standard patent. Hence, any point in the area formed by $A, B$, and $C$ represents an unambiguous welfare improvement over the initial point $A$ (which represents a non-leveraged twenty-year patent). For example, a 21.5-year leveraged patent has the same deadweight loss as a twenty-year standard patent, but higher patentee profits. An eighteen-year leveraged patent has the same incentives to innovate as a twenty-year standard patent, but smaller deadweight loss. 


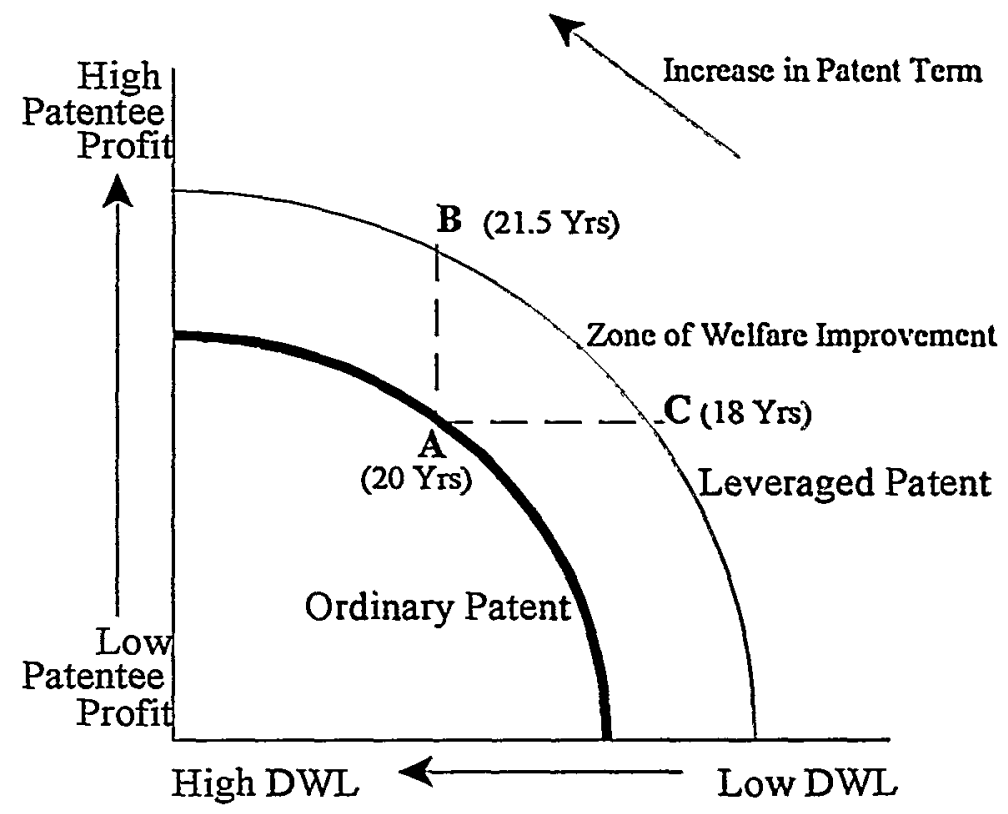

FIGURE 1: "WELFARE POSSIBILITY FRONTIERS" FOR PATENTS WITH AND WITHOUT LEVERAGE

Table 4 provides a numerical example. It shows that as compared with a conventional twenty-year patent, a leveraged patent of the same length generates $2.8 \%$ higher profits and $9.4 \%$ less deadweight loss in net present value terms. To reduce static mefficiencies while maintaining the original level of profitability, policymakers could cut the patent length to roughly 18 years, diminishing deadweight loss by almost $13 \%$, while keeping the patentee's profits the same. Alternatively, to raise incentives to innovate without increasing static inefficiency, the patent term could be extended to approximately 21.5 years, thereby increasing incentives to invest in R\&D by $10.7 \%$, while leaving deadweight loss shightly below that of a conventional patent. There is such a thing as a free lunch! 
Table 4: Innovation Incentive and Deadweight Loss Under Conventional \& Leveraged Patents, for Alternative Patent Lengths ${ }^{159}$

\begin{tabular}{|c|r|r|r|r|}
\hline & $\begin{array}{c}\text { Conventional } \\
\text { Patent Term }\end{array}$ & \multicolumn{3}{|c|}{ Leveruged Patent } \\
\hline & 20 years & 20 years & 18 years & 21.5 years \\
\hline NPV Patentee's Profits & 21,284 & 21,878 & 21,275 & 24,505 \\
\hline $\begin{array}{c}\text { Percent Increase } \\
\text { vs. Col.1 }\end{array}$ & - & 2.8 & 0.0 & 10.7 \\
\hline \begin{tabular}{c} 
NPV Deadweight Loss \\
\hline $\begin{array}{c}\text { Percent Decrease } \\
\text { vs. Col.1 }\end{array}$
\end{tabular} & 10,642 & 9,647 & 9,275 & 10,452 \\
\hline
\end{tabular}

\section{Tailoring and Defaults}

An obvious problem with the foregoing analysis is that it assumes that pohicymakers can determine which patents are subject to trademark leverage and tailor their responses accordingly. In reahity, pohcymakers may often be unable to do so. The state of current theorizing in this area is very unsatisfactory, and as our earlier discussion makes clear, ${ }^{160}$ we lack the ability to make accurate predictions about when brand loyalty, and hence trademark leverage, are likely to be important. One should be wary of any theoretical improvement that requires superhuman policymakers or unfeasible information to make it more easily implemented.

This does not mean that our findings are of no policy relevance, however. We suggest that informational constraints can to some extent be overcome by allowing patentees to tailor their own patent or trademark protection from a menu proposed by regulators. Technically, we propose a separating equilibrium, in which policymakers can imduce patentees to behave optimally even when pat-

${ }^{159}$ Based on Appendix, assuming myopic consumers and parameter values $a=100$, $b=1, S=10, r=0.1$.

${ }^{160}$ See supra text accompanying notes 85-99. 
entees have private information (about the extent of leverage) that regulators do not know. ${ }^{161}$

For example, suppose that policymakers determine that they wanted to reduce deadweight loss below that contemplated under current patent law (for non-leveraged patents) and are happy to keep patentee's incentives to innovate at current levels. They could then offer patentees a choice between a patent lasting twenty years with no trademark leverage and a leveraged patent of eighteen years. As Table 4 demonstrates, these two schemes produce the same profits for the patentee when leverage is possible. Furthermore, for those cases in which patentees recognize that they are not in a position to exploit leverage, ${ }^{162}$ they will simply choose the standard patent term (with no trademark protection, which would be valueless to them im any case).

A comparison of columns 1 and 3 in Table 4 reveals that this "tailoring" approach guarantees that all patentees will have at least the level of protection contemplated by Congress (compare column 1 , row 2 with column 3 , row 2). For those patentees who exploit trademark leverage, deadweight loss is reduced by almost $13 \%$ compared to conventional patents. Policymakers do not have to know whether patentees plan to exploit trademark leverage or not. By offering a menu of choices, patentees can be induced to select the option that reduces deadweight loss by as nuch as possible without sacrificing incentives to innovate.

There are two problems with this approach that must be noted. First, although policymakers do not need to know which firms or industries will exploit trademark leverage and which will not, they do need to know the relevant paraineter values underlyimg the pat-

${ }^{161}$ Professors Michael Rothschild and Joseph Stiglitz were the first to describe an equitibrium in which one party (the insurer) induces separation between two unknown types (of insureds) by offering a menu of contracts that lead each type to choose a different contract. See Michael Rothschild \& Joseph Stiglitz, Equilibrium in Competitive Insurance Markets: An Essay on the Economics of Imperfect Information, 90 Q.J. Econ. 629 (1976). Professors Ian Ayres and Robert Gertner introduced ideas of pooling and separating equilibria into legal theory. See Ian Ayres \& Robert Gertner, Filling Gaps in Incomplete Contracts: An Economic Theory of Default Rules, 99 Yale L.J. 87 (1989).

${ }_{162}$ As we explained earlier, in Section II.B, not all products are equally "leverageable." Presumably, patentees have better information than regulators about whether they plan to exploit brand loyalty in marketing their patented innovation, and if so, how much. 
entee's decision problem, including the size of switching costs, interest rates, and the slope of the demand curve. This information is important because it determines the profitability of the leveraged patent, and hence sets the patent term that provides equivalent profits to a twenty-year term with no leverage.

This problem is not as serious as it first seems, however. Suppose that policymakers are completely ignorant of the underlying parameters and offer patentees a choice between nineteen years of patent protection with trademark protection on expiration or twenty years with no trademark protection. Some patentees who select the first option would have to be willing to give up an additional year of protection (as illustrated by Table 4), so the policy does not achieve the minimum feasible deadweight loss. Nevertheless, it still reduces deadweight loss as compared with the status quo and hence represents an unambiguous improvement. ${ }^{163}$

A more significant difficulty is that the menu approach only works in one direction. Suppose that policymakers wish to provide more incentives to innovate than currently contemplated under a non-leveraged twenty-year patent. Table 4 reveals that with leverage, patent terms could be extended to 21.5 years without increasing deadweight loss over a twenty-year conventional patent. This would have the effect of increasing patentee profits by almost $11 \%$, as in column 4 . There is, however, no way to offer this option only to those firms that wish to exploit trademark leverage. All firms will prefer a 21.5-year patent to a twenty-year patent, regardless of whether they will utilize trademark leverage or not. But if the patentee does not utilize leverage (and, thus, cuts prices while the patent is in effect), then the longer patent term unambiguously increases deadweight loss. ${ }^{164}$

\section{OBJECTIONS AND ADDITIONAL FACTORS}

In this Part, we discuss three additional factors that might complicate the story we want to tell about the importance of trademark

${ }^{163}$ A similar argument can be made in reverse: If policy makers set the leverageinclusive patent term too low, no firms would prefer this alternative to the status quo. But this simply leaves us where we started and does no harm.

${ }^{164}$ Trademark leverage is thus like a string: It can be used to pull patentees in one direction (same profits but lower deadweight loss), but not to push them in the other (higher profits, same deadweight loss). 
leverage and brand loyalty as a supplement to patent protection. Does it matter that firms can seek to develop brand loyalty by advertising, rather than by expanding output, during the patent period? How does the introduction of discounting and multiple periods affect our results? And, finally, is our model vulnerable to the empirical finding that, at least for certain pharmaceuticals, prices in reality rise-rather than fall-on the expiration of the patent?

\section{A. Advertising}

In the real world, patentees always have the option of trying to build brand loyalty by advertising as well as, or instead of, cutting prices and developing a base of experienced users. How does the possibility of advertising affect our conclusions?

One possibility is that advertising could substitute for greater output as a method of creatmg brand loyalty. If patent holders respond to the possibility of tradeinark leverage by attemptimg to create loyalty through increased advertising, rather than through increased sales, then the efficiency gains we described earlier may not be realized. ${ }^{165}$ While this is certainly a possibility, we argue that neither the theory nor the empirical evidence support this view.

We turn first to considerations of theory. In a classic article written nearly fifty years ago, Professors Dorfman and Steiner devised a simple formula for the optimal ratio of advertising expenditures to total sales of a product. ${ }^{166}$ Their equation says that the optimal advertising/sales ratio is

$$
\alpha=-\eta_{d} / \eta_{p},
$$

where $\eta_{a}$ is the elasticity of quantity sold with respect to advertising and $\eta_{p}$ is the conventional price elasticity of demand. ${ }^{167}$

${ }^{165}$ On the basis of their asymmetric information model of consumer search costs, Moshkin and Shachar suggest that the growth in the total volume of products available increases 'individuals' ignorance of the attributcs of the alternative [products they do not consume]. The increase in ignorance is the asset of the large and estabhished firms. Advertising rather than price cuts are the penetration tool of new firms and those which are growth-oriented." Moshkin \& Shachar, supra note 98, at 28. These broad conclusions lack einpirical support, however.

${ }^{16}$ Dorfman \& Steiner, supra note 18 , at 828.

${ }^{167}$ Id. Technically, $\eta_{\text {, }}$ is the percent change in quantity demanded from a $1 \%$ increase in advertising, while $\eta_{p}$ is the percent change in quantity demanded from a $1 \%$ decrease in price. 
To see the intuition for this result, imagine that the firm can increase its quantity sold by one unit by neans of either a $\$ x$ increase in advertising or a $\$ z$ drop in price. A profit-naximizing firm will want the incremental profit from either course of action to be the sanie. The more effective advertising is (the greater the demand shift per dollar spent), and the less effective cutting prices are (the snaller the moveinent along the demand curve per dollar drop in price), the better the advertising looks relative to cutting prices.

To apply the Dorfman/Steiner insight in our context, we begin by noting that the case for tradenark leverage is strongest for experience goods, which, as we stated earlier, are products whose attributes cannot be appreciated except through actual consumption. But the more a product resembles an experience good, the less hikely it would be that advertising could substitute for actual use of the product in creating new demand. In the Dorfman/Steiner terminology, $\eta_{a}$-the efficacy of advertising-should be low for experience goods. It follows that patentees would be more likely to develop brand loyalty by inducing additional use (increasing quantity and decreasing price), rather than by expanding advertising.

Moreover, we would expect to see more price-cutting and less advertising for those products where leverage is strongest. Even if we assume that leverage has no effect on the efficacy of advertising, the fact of leverage increases the long run price elasticity of demand. That is, a given drop in price has a bigger effect on total quantity demanded over the two periods with leverage than without it. Hence, not only does leverage niake the numerator of the Dorfman/Steiner ratio snialler, it plausibly nakes the denominator larger.

In sum, patentees should engage in less advertising per dollar of sales with leverage than without it. Regardless of whether advertis-

${ }^{163}$ The pioneering work of Phillip Nelson demonstrates that advertising may be a credible signal of product quality, even for "experience goods" for which important qualities are discernable only by direct consumption of the good. See Nelson, Advertising as Information, supra note 46 , at 732 . Advertising expenditures are a credible signal of product quality because they are only profitable if the firm is in business for the long term, and not a fly-by-night operation.

Professor Henry Smith pointed to another reason why $\eta_{a}$ may fall as the patent nears expiration: Advertising for the patented product may spillover to its generic competitors, so that some of the benefit to the patentee 'leaks' away to its rivals. This of course makes advertising less attractive to the patentee. 
ing enhances or reduces welfare, the effects of leverage-the fact that selling more now allows for more sales later as well-will, other things equal, tend to reduce advertising. All this does not say that the patentee will engage in no advertising. It merely suggests that advertising will not be an attractive substitute for cutting prices in the case most important to our argument.

There is not much empirical evidence on the relationship between patents and advertising. One recent and extremely careful study by Professors Berndt, Ling, and Kyle, however, looked at marketing expenditures for patented drugs as the patent lapsed and the products were remtroduced as over-the-counter medicines. ${ }^{169}$ They found that marketing declined substantially as patent expiration neared. (The decline was even more pronounced with the onset of generic competition after the patent ended.) This is precisely the time when the patentee will be increasing output and lowering price to generate new customers and brand loyalty. ${ }^{170}$ Hence, the empirical evidence is at least consistent with our prediction that leverage leads to less advertising, rather than more. Surveying a variety of studies, Professor Robinson and his colleagues support this conclusion, noting that "imdustry studies and crosssectional evidence consistently show that market pioneers spend less as a percentage of sales on advertising and promotion."171

\section{B. Discounting and Dynamic Issues}

Our simple model has only a single period in which the patent is in effect, followed by a single period when the product is protected, if at all, only by its trademark and brand loyalty. This Section demonstrates the conditions under which our conclusions are sensitive to this assumption. A more complex model-in which patent protection lasts for twenty years and is followed by trademark protec-

${ }^{169}$ Ernst R. Berndt et al., The Long Shadow of Patent Expiration: Do RX to OTC Switches Provide an Afterlife? 2 (Nat'l Bureau of Econ. Research, Conference on Research in Income and Wealth, Symposium on Scanner Data and Price Indexes, Sept. 15-16, 2000).

${ }^{10}$ Id. at 20 tbl. 1. For Tagamet, the authors found that total marketing expenses as a percent of sales fell by $43.1 \%$ as patent expiration approached and by $30.1 \%$ following expiration. ("Total" here means pages of journal advertising plus number of sales visits to doctors.) For Zantac, the figures are $59.8 \%$ as the patent neared expiration, with an additional $13 \%$ after expiration, for a total reduction of $72.8 \%$. Id.

${ }^{171}$ Robinson et al., supra note 107 , at 18. 
tion extending into the infinite future-does not alter the results as long as consumers have a short time horizon or do not anticipate the future.

When consumers are infinitely-lived and forward-looking, however, the patentee's price can not deviate much from the competitive level, since consumers will wilhingly incur a switching cost to "buy" the opportunity to purchase at the competitive price for the infinite future unless the savings froin doing so are very small. Hence, brand loyalty essentially vanishes, and our story about buildimg brand loyalty by increasing output is no longer plausible. ${ }^{172}$

The more elaborate model generates two important conclusions. First, the trademark-leveraged patentee will always produce more than the "pure" patentee (one who generates no brand loyalty or has no trademark protection) in every period before the patent expires. Second, the leveraged patentee's optimal output rises over time during the patent period, with the bulk of the increase as the patent nears expiration. Output then drops once the patent expires.

We summarize these conclusions in Figure 2, which graphs optimal output, assuiming that leverage is possible and that the amount of brand loyalty depends on the average volume of consumers served during the patent period. ${ }^{173}$ It shows that the patentee's optimal output in the first year of the patent is infinitesimally above the single-period monopoly level. As expiration approaches, however, output rises to more than $30 \%$ above the single period monopoly level, then falls substantially once the patent expires. Our theory is thus at least roughly consistent with the dynamics dis-

${ }^{172}$ We formalize this insight in the Appendix and demonstrate that there will still be a small brand-loyalty effect even in this case. See infra Appendix. Note that this problem is common to "rational expectations"-type critiques of models with myopic behavior. It has the potential to occur in almost every model of switching costs, although it does not appear to have received much attention because most such models use only two periods.

Brand loyalty is both intuitively plausible and one of the best-documented facts in the marketing literature. See Kotler, supra note 94, at 444-45, 447, 449; I.P.L. Png \& David Reitman, Why Are Some Products Branded and Others Not?, 38 J.L. \& Econ. 207 (1995). If it turns out to be incompatible with the assumption of perfect foresight, so much the worse for that assumption.

${ }^{173}$ See infra Appendix for an explanation of the technical details. The demand curve is assumed to be linear with parameters $a=100$ and $b=1$. The switching cost is 10 , and the interest rate is $10 \%$. We assume that consumers look only at the current period, rather than predicting their own future behavior (myopia). 
cussed in the case studies, where patentees seemed to reserve the bulk of their price-cutting and attempts to build market-share for the patent's twilight years.

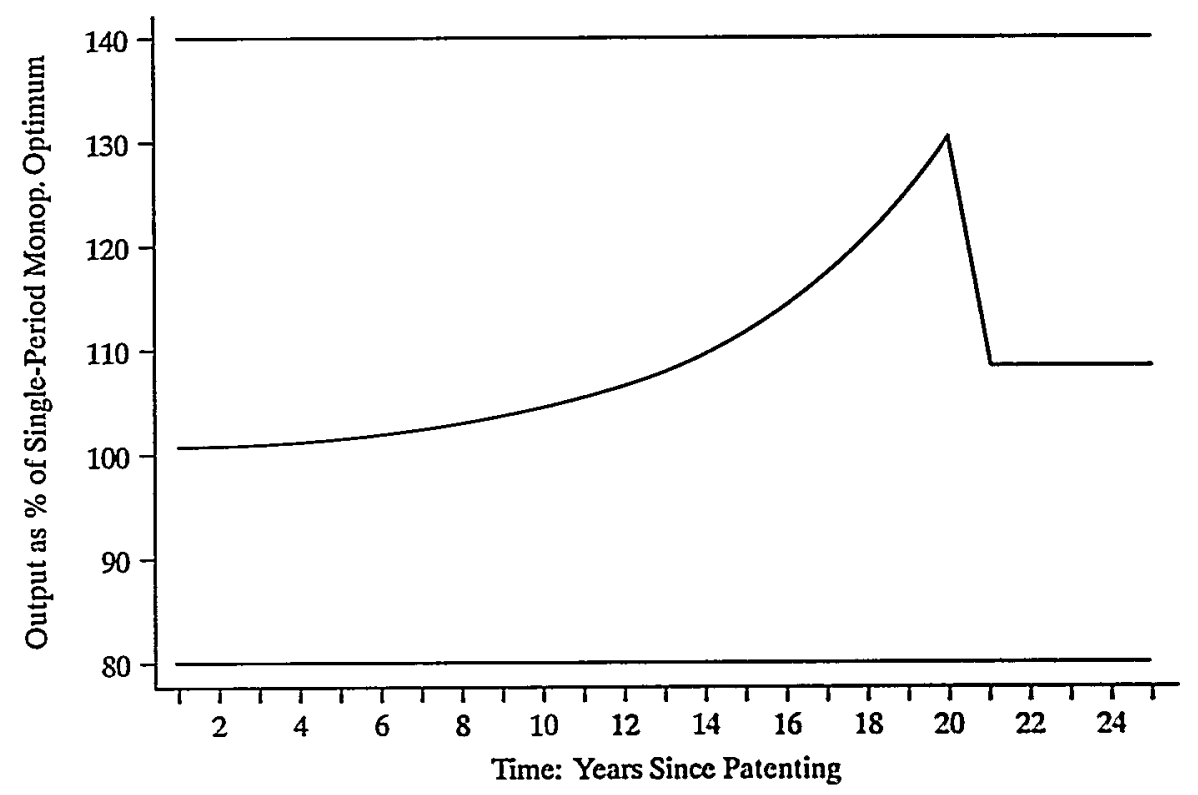

Figure 2: PATENTEE'S OPTIMAL OUTPUT OVER TIME GIVEN Trademark LeVerage, as Percent of Single-Period MoNopoly OPTIMUM

\section{Prices Rise on Expiration of the Patent?}

Some theories predict that the price of a patented product will not fall, and may in fact rise, in response to the entry of generic competition, when the market is divisible into brand-loyal and price-sensitive consumers. ${ }^{174}$ Moreover, there is empirical evidence

${ }^{174}$ See Richard G. Frank \& David S. Salkever, Generic Entry and the Pricing of Pharmaceuticals, 6 J. Econ. \& Mgmt. Strategy 75, 76-77 (1997) [hereinafter Frank \& Salkever, Generic Entry]; Richard G. Frank \& David S. Salkever, Pricing, Patent Loss and the Market for Pharmaceuticals, 59 S. Econ. J. 165, 165-66 (1992). 
that this happens, at least in some instances. ${ }^{175}$ Is this a problem for our theory?

We start by noting that pricing in Period 2 has no efficiency consequences in our model. As long as there are firms entering at the competitive price, then every consumer who should be served in the second period will be. True, soine will pay more for the product than they could if they bought from the entrants at the competitive price, and this price discrimination does, of course, have distributional consequences that we might care about independently. There are, however, no distortions to worry about in the post-patent period, and the fact that the incumbent firm charges a higher price to its brand-loyal customers is not, per se, an efficiency problem. ${ }^{176}$

We do, however, care about leverage-that is, whether the possibility of retaining some customers in Period 2 induces the patentee to raise output and lower prices in Period 1. Is the raising of prices in Period 2 (focusing only on brand-loyal customers) inconsistent with our prediction that the patent holder will increase output in Period 1 to create additional loyal users? Although our model predicts that the patentee's price for the branded product will fall, rather than rise, when facing generic competition, the answer to this question is "no."

We need to coinplicate our story by taking account of heterogeneous brand loyalty by, for example, allowing for randomly distributed switching costs in Period 2 among those who bought the product in Period $1 .^{177}$ It still makes sense for the patentee to expand sales in Period 1 in the hopes of landing someone with a (randomly) high switching cost--someone who can then be kept in Period 2, even at a price that is much higher than the generic substitute. If only a small fraction of the population has high switching

\footnotetext{
${ }^{175}$ Berndt and his colleagues found that "neither Tagamet Rx nor Zantac Rx adopted a policy of competing with generics on price following patent expiration, and instead increased prices. As a consequence, they lost very substantial market share, but retained sales to a small, relatively price-insensitive segment of brand-loyal consumers." Berndt et al., supra note 169, at 23. Frank \& Salkever, Generic Entry, supra note 174 , at 83 , present further empirical evidence of this behavior vis-a-vis other brand name drugs.

${ }^{176}$ Michael Pereira pointed out to us that further distributional problems might arise if, for example, low-incoine or poorly informed consumers remain loyal to the patentee's brand purely because they lack information about the existence or comparability of the generic substitute.

${ }^{17}$ For a model of this type, see Gabszewicz et al., supra note 71, at 399-401.
} 
costs, it may make sense to charge $10 \%$ of the people a high price, abandoning the other consumers to generic competition, rather than charging, say, $30 \%$ of the consumers a lower price.

In sum, the fact that some sellers raise, rather than lower, prices on expiration of their patents does not reverse any of the conclusions of our model. Of course, the extent of leverage is still an empirical question, but the existence of leverage is not at all imcompatible with an upward rather than a downward movement of price once the patent expires.

\section{Alternative Proposals}

A final objection one might raise is that there are alternative mechanisms for reducing the deadweight loss associated with patent grants. The two competing proposals are Professor Tandon's model of patents with optimal compulsory hicensing ${ }^{178}$ and the model of probabilistic enforcement created by Professors Ayres and Klemperer. ${ }^{179}$ Essentially, both of these proposals are predicated on the sanie principle: reducing the patentee's protection while extending the patent tern. While consideration of these competing proposals is certainly illuminating, it bears emphasis that neither of them concerns the problem we analyze-the interaction between different modes of intellectual property protection.

Thus, neither Tandon's nor Ayres and Klemperer's proposal presents a facial challenge to our findings. ${ }^{180}$ Furthermore, the competing inodels are completely theoretic, whereas leveraged patents are a real world phenomenon. Notwithstanding these key differences, we will show that insofar as reducing the deadweight loss associated with patent protection is concerned, leveraged patents have both important theoretic and practical advantages over both compulsory licensing and probabilistic enforcement.

\footnotetext{
${ }^{178}$ See Pankaj Tandon, Optimal Patents with Compulsory Licensing, 90 J. Pol. Econ. 470 (1982).

${ }^{179}$ See Ian Ayres \& Paul Klemperer, Limiting Patentees' Market Power Without Reducing Innovation Incentives: The Perverse Benefits of Uncertainty and NonInjunctive Remedies, 97 Mich. L. Rev. 985 (1999).

${ }^{180}$ To a degree, our proposal is compatible with either of them, since one could imagine, for example, leveraged probabilistic patents, or leveraged patents with compulsory licensing.
} 


\section{Compulsory Licensing}

In an important theoretical article, Tandon suggests an ideal patent system with optimal royalty rates-ones that "optimally trade off the negative incentive effects of licensing with the positive consumer price effects" ${ }^{181}$ and an infinite patent life. His basic insight is that society would inaximize the gains from patent protection by subjecting all patents to compulsory licensing and simultaneously lengthening the life of patents. ${ }^{182}$ The compulsory rates force the patentees not to price inonopolistically, while the longer protection term preserves the incentive to invest in R\&D. The lion's share of the gains coines from the reduction in the deadweight loss engendered by patents; a considerably smaller improvement results froin extending the protection term.

Leveraged patents have several advantages over compulsory licensing. First, Tandon's apparatus critically depends on the setting of optimal compulsory hicense rates, presumably by the courts or Congress. This task, however, is well beyond the ability of most judges or lawmakers. In fact, courts and Congress face tremendous difficulties deciding reasonable royalty rates in intellectual property cases. ${ }^{183}$ These difficulties stem from the uniqueness of intellectual goods and from the risk element inherent in the inventive process. The royalty rate must adequately coinpensate the patentee not only for the cost of producing the patented invention, but also for the cost of the many research projects that have failed to yield a patentable result. Setting the royalty rate too low would have a chilling effect on innovation; setting it too high would reintroduce the problem of deadweight loss and might even aggravate it.

As Tandon succinctly cautions, "[f]urther work is needed to suggest practical approaches to realizing the potential welfare gains which have been discussed." selection scheme hes in its simplicity. Leveraged patents do not re-

181 Tandon, supra note 178 , at 471 .

182 Id. at 484.

${ }^{183}$ See Robert P. Merges, Contracting Into Liability Rules: Intellectual Property Rights and Collective Rights Organizations, 84 Cal. L. Rev. 1293, 1299 (1996) (identifying problems of a compulsory licensing scheme including wasted lobbying costs, changed conditions, and the potential for legislative "lock-in" rendering the royalty schedule inflexible over time).

${ }^{184}$ Tandon, supra note 178 , at 484 . 
quire any complicated determinations. Moreover, because the patentee decides wliether to leverage, leveraged patents are certain not to harm the incentive to innovate.

Second, Tandon's compulsory licensing scheine presumably requires the setting of license rates for every patent issued by the patent office, or at least for any patent for which there is a potential licensee. This process is both expensive and wasteful. It requires eitler a judicial or an administrative determination of a "price" for an enormous number of inventions, many of which turn out to be of negligible social value. Leveraged patents, however, are self-effecting. Not only does our scheine not require an expensive price setting ineclianism, but it also adopts an ex post approach to the problein, ensuring that only patents of sufficient social value will continue to enjoy legal protection.

Finally, and inost obviously, Tandon's proposal requires a legislative overhaul of the patent system. Currently, patents are not subject to compulsory licenses. Given the recent trend to expand and solidify intellectual property protection, the introduction of compreliensive compulsory licensing is unlikely. Leveraged patents, by contrast, are an existing plienoinenon.

\section{Probabilistic Enforcement}

A different ineclianism for reducing tlie deadweiglit loss of patents lias been proposed by Ayres and Kleinperer. Eschewing the drawbacks of compulsory hicensing, their proposal rests on the dual principles of uncertainty and delay. Specifically, they propose that patentees be allowed to bring lawsuits against infringers only at the end of the patent term, whicl would limit the remedy to monetary dainages. ${ }^{185}$ Even then, lowever, patentees would not be able to collect tlie full dainage they suffered, but ratlier a fraction of that anount to be determined probabilistically. As Ayres and Klemperer explain, under tlieir proposed regiune,

the patentee of a true innovation-that is, an innovation deserving immediate and certain enforcement under current lawwould liave to wait until the day the patent expired to learn if a court would award damages for any past infringement; and the

${ }^{18 s}$ Ayres \& Klemperer, supra note 179, at 988, 994. 
court would make this determination simply by flipping a weighted coin with, say, only an $80 \%$ chance of enforcement. ${ }^{186}$

The aim of the partial enforcement is to encourage a certain level of patent infringement. The infringing production would "expand industry output and decrease the market price," reduce the deadweight loss generated by patents. To compensate patentees for the drop in their returns, Ayres and Klemperer propose that patent duration be extended. They noted that the necessary extension may be approximated by "[m]ultiplying the duration by the reciprocal of the probability of enforcement." ${ }^{188}$ For example, if the probabihty of enforcement is $50 \%$, the duration should be increased by $200 \%{ }^{189}$

Leveraged patents are superior to probabilistic enforcement on several grounds. First, the delay and uncertainty Ayres and Klemperer seek to introduce might not only increase the likelihood that valid patents will not be enforced, but also that invalid patents will be. Indeed, the passage of time might reinforce the tendency of the courts to uphold questionable patents, ${ }^{190}$ especially those that achieved commercial success. ${ }^{191}$ Leveraged patents do not give rise to this risk. Second, Ayres and Klemperer seek to increase production of patented inventions by encouraging infringements. ${ }^{192}$ The downside of this mechanism is the notoriously high cost of patent litigation. ${ }^{193}$ As Ayres and Klemperer admit, "[s]ome forms of uncertainty and delay would undoubtedly lead to litigation costs

${ }^{186}$ Id. at 995.

${ }^{187}$ Id. at 993.

${ }^{188}$ Id. at 1009.

${ }^{189}$ Id.

${ }^{190}$ Id. at 1020 (noting that the Federal Circuit's "protection of patent qua property becomes an end in itself, trumping all other conceptions of the good"). This problem is compounded by the tendency of patent examiners to issue poor culuality patents because of the increase in the volume of patent applications. See Robert P. Merges, As Many as Six Impossible Patents Before Breakfast: Property Rights for Business Concepts and Patent System Reform, 14 Berkeley Tech. L.J. 577 (1999).

${ }^{191}$ See Robert P. Merges, Commercial Success and Patent Standards: Economic Perpectives on Innovation, 76 Cal. L. Rev. 803, 816 (1988) ("[T]oday, nonintrinsic evidence ... referred to as the 'secondary' or 'objective' considerations, ... occupies an increasingly important place in nonobviousness determinations."). The most important secondary consideration is the commercial success of the invention.

${ }^{192}$ Ayres \& Kleinperer, supra note 179, at 993.

${ }^{193}$ Anyone who doubts the importance of litigation costs in patent enforcement need only look at this advice to patentees:

Prospective counsel will generally request anywhere from one-third to one-half 
certainty and delay would undoubtedly lead to litigation costs that swamp the benefits of limited interim infringement ...." ${ }^{\text {"19t }}$ Leveraged patents, by contrast, do not exacerbate litigation costs; they do not even necessitate judicial intervention. Third, Ayres and Klemperer rely on the average depreciation rates of patents from various industries in setting enforcement rates. ${ }^{195}$ This means that soine individual inventors would be undercompensated by the judicial determination, while others would be overcompensated. Thus, Ayres and Klemperer inanage to preserve the incentive to innovate only on average, but not in each individual case. Our proposal avoids this problein.

Finally, as is the case with Tandon's proposal, Ayres and Klemperer's proposal requires a comprehensive reform of the patent systen. To work effectively, it would require sweeping changes not only in patent remedies, but also in hitigation processes. Such changes are highly unlikely. In contrast, leveraged patents are possible under the existing patent system, and firms liave been taking advantage of this possibility.

\section{CONCLUSION}

In this Article, we lave sought to fill a curious gap between intellectual property theory and practice. The theory consistently treats patents, copyrights, and trademarks as separate forms of protection, each independent of the others. By contrast, real world

of the total recovery. Unless this number is a multiple of the typical \$1.5 million hitigation cost, in all likelihood he will not be interested. Simple arithmetic gives us $\$ 15$ million in damages as a minimum threshold to arouse the curiosity of the potential counsel to continue to listen to the rest of your story. Practically speaking, however, most counsel will not consider a case where potential damages are Iess than $\$ 100$ million. This amount of damages corresponds roughly to a half billion dollars in annual infringing revenues....

Deciding When And How To Enforce Your Patent, Mondaq Int'l Briefing, Jan. 12, 2001 , at 6, available at 2001 WL 8986875.

The situation may be even worse in the United Kingdom. See, c.g., Rosemary Bennett \& Jean Eaglesham, Legislation to Mandate Greater Damages for Patent Breaches, Fin. Times (London), Nov. 1, 2001, at 4. ("The UK is known to offer a difficult combination of high costs and relatively low damages for people trying to defend patent rights.... James Dyson, for example, is estimated to have spent more than [\$3 million] on patent litigation against Hoover over his Dyson vacuum cleaners.").

${ }_{10}$ Ayres and Klemperer, supra note 179, at 1014. To avoid this problem, Ayres and Klemperer call for a reform in the patent system.

${ }^{195}$ Id. at 1010-11. 
businesses have long combined different modalities to increase their competitive advantage over rivals. While the discrete analysis has shed light on each of the subfields of intellectual property, it has obfuscated the important interconnections among them, and obscured the efficiency effects therein. By adopting a unified perspective, we have been able to show that certain combinations of intellectual property protection give rise to inportant synergies, and thereby enhance economic efficiency. Specifically, we have demonstrated that the availability of subsequent trademark protection mitigates the prochivity of both patentees and trade secret holders to price monopolistically.

Our analysis of the synergistic effects anong various modes of intellectual property has yielded important descriptive, normative, and methodological inplications. Descriptively, we have shown that the deadweight loss of patent and trade secrecy protection is lower than is commonly believed, and that the incentives to innovate are higher. Normatively, we have called for a reversal of the prevailing judicial hostility to leveraged patents and explained how the law can take advantage of leveraged patents to improve the tradeoff between dynamic and static efficiencies in innovation policy. Most importantly perhaps, methodologically, we have demonstrated the need for an integrated analysis of intellectual property.

When synergies exist, exclusive focus on the parts often leads to a distorted perception of the whole. While there are inany obvious differences between the study of intellectual property and an elephant parable, they do share a common moral: Both point to the importance of an integrated analysis. 


\section{APPENDIX: A DYNAMIC PRICING MODEL}

Our simple model had only a single period in which the patent is in effect, followed by a single period when the product was protected only by its trademark and brand loyalty. Our conclusions, however, are largely insensitive to this assumption. A more complex model-in which patent protection lasts for twenty years and is followed by trademark protection extending into the indefinite future-does not alter the results, as long as consumers have a short time horizon or do not anticipate the future. ${ }^{136}$ Moreover, the dynamic model yields a result that is supported by the case studies we discussed earher: Patentees seeking to build brand loyalty will not increase output and cut prices uniformly over the patent period. Instead, they will cut output more heavily as the patent nears expiration.

Understanding the dynamics of brand loyalty and patent pricing requires a brief discussion about how brand loyalty is generated and maintained over time. ${ }^{197}$ While there are many plausible formulations, we adopt a simple specification, in which the postpatent switching cost is a one-shot amount that is fixed for all consumers for all time; the number of consumers with switching costs depends on the average number served by the patentee over the twenty periods during which the patent is in effect. This formula-

${ }^{196}$ See discussion supra Section IV.B for an explanation of why our theory about building brand loyalty by increasing output essentially vanishes when consumers are infinitely-lived and forward-looking. There will, however, still be a small brand-loyalty effect even in this case, but a common problem of brand loyalty stories of any kind is that they are not truly compatible with "rational expectations" on the part of consumers.

${ }^{197}$ Various alternatives seem behaviorally plausible, including:

1. The size of an individual customer's switching cost, $S_{n}$ is a positive function of the number of purchases made by that customer during the patent period;

2. The duration of the customer's switching cost-defined as the number of purchases of the rival product that the custoiner inust make before switching costs are eliminated-is a positive function of the number of purchases during the patent period; or

3. Either the size or duration of post-patent brand loyalty (or both) depends on both the number of previous purchases and their timing. For example, suppose-as might be reasonable-that brand loyalty decays over tine. A customer whose only purchase was in Period 1 would then have a lower switching cost than one whose only purchase was in Period 20, immediately before the patent expired. 
tion imphies that the patentee can allocate its output over the twenty-year patent period in any way it wishes, but it is only the total output over the period as a whole that determines its loyal customer base after the patent expires. ${ }^{198}$

As is traditional in these situations, we solve the model by working backwards. That is, we first describe what price the (former) patentee can charge its stock of loyal customers once the patent has expired, assuming that the number of loyal customers is fixed and the patentee can only change the price it charges. We then use this information on optimal pricing in the post-patent period to solve for the optimal quantity of loyal customers created while the patent is im effect. Simultaneously, we show how the patentee will allocate its output over the twenty-year patent life in order to achieve this optimal quantity.

\section{Post-Expiration Dynamics}

Since we are now dealing explicitly with time, some additional notation is necessary. We denote by $r$ the annual interest rate, and by $\delta$, the discount factor, which is simply $1 /(1+r) . P_{p, t}$ denotes the price charged by the (former) patentee in period $t$, and $P_{\mathrm{c}}$ denotes the competitive price.

If we allow for an infinitely-lived consumer and an indefinite trademark duration; the patentee's customers face a whole series of "consumption plans" once the patent expires in Period 21. The first alternative is to buy from the competitor immediately, paying price $P_{c}$, plus switching cost $S$, this period. Since the switching cost is modeled as a one-time only payment, once a loyal consumer has tried the generic product, she can continue to purchase it at its quoted price, $P_{c}$, forever after. A second consumption plan is to buy from the patentee at the price being charged this period, $P_{p, 2 l}$, and switch to the competitor, at price $P_{c}+S$, next period, paying $P_{c}$ forever after. A third is to buy from the patentee for two periods and then switch, and so on. Knowing this, the patentee must set current and future prices so that its loyal customers are indifferent between switching and remaiming loyal in each period, including

${ }^{198}$ In other words, producing fifty units each year for twenty years yields the same number of loyal customers as producing twenty-five units for the first ten years and seventy-five units for the second ten years of the patent's life. 
the current one. In other words, the customer must expect to pay the same amount in present value whether she switches today, tomorrow, or not at all.

Note, too, that the present value of $P_{c}$ each period from time $t$ until infinity is just $P_{c} / r .{ }^{199}$ This amount has to be discounted even further, however, to reflect the fact that the customer does not begin paying $P_{c}$ immediately, but instead must first pay $P_{c}+S$ and then wait at least one period before being able to buy without any switching cost. ${ }^{200}$ All this means that the consumer faces a choice among the following:

Switch Immediately: $\left(P_{\mathrm{c}}+S\right)+\delta P_{c} / r$, vs

Switch Next Period: $P_{p_{1} 21}+\delta\left(P_{c}+S\right)+\delta^{2} P / r$, vs

Switch in 2 Periods: $\left.P_{p, 21}+\delta P_{p, 22}+\delta^{2}\left(P_{c}+S\right)+\delta^{3} P\right\rfloor r$, and so on.

The former patentee will choose the maximum possible $P_{\text {, }}$ at each poimt in time-the value that keeps the consumer just indifferent between buying from it and switching to the competitor. Hence, setting the first equation equal to the second and solving, we have:

$$
P_{p, 21} \approx(1-\delta) S+\delta P_{c^{*}}{ }^{201}
$$

Given $P_{p, 21}$, we can then solve for the patentee's price in the second period, $P_{p, 22}$, by setting the second equation equal to the third. Agam, the result is that $P_{p, 22} \approx(1-\delta) S+\delta P_{c}=P_{p, 21}$. In short, the patentee's price does not change over time. This price is just sufficient to make the patentee's prior customers indifferent between switching and remaining loyal in each period-the present dis-

${ }^{199}$ How much would one have to put into a bank account to yield $P_{c}$ each year forever? A deposit of $P_{c}$ yields $P_{c} \times r$ per year in interest when the interest rate is $r$. Hence, a deposit of $P_{c}^{c} / r$ will pay $P_{c}$ in interest, which can be removed each year in perpetuity without touching the principal.

${ }^{200}$ To solve for the time path of the patentee's post-expiration price, we assume that there is a fixed stock of infinitely-lived "experienced" customers, each of whom has a constant switching cost, $S$. Hence, the demand curve is no longer relevant and the problem is one of choosing price, rather than quantity. We solve for the optimal stock of consumers below.

${ }^{201}$ Technically, $P_{p, 21}=(1-\delta) S+P\left[1-\delta+\left(\delta-\delta^{2}\right) / r\right]$, which is approximately $(1-\hat{\mathrm{o}}) S+\mathrm{o} P_{\mathrm{c}}$ for small values of the interest rate $r$. 
counted value of the consumption plan is the same whether the customer switches im Period 1,2,3, and so on, or not at all.

Note that the analysis so far has assumed that the patentee's consumers have perfect foresight, at least once the patent has lapsed. That is, they compare today's switching cost with the benefit of being able to buy from the lower-priced competitor for the rest of time. This naturally limits the patentee's ability to markup her product over that of her rivals-the limit is not the switching cost per se, but rather the present discounted value of the savings from switching to the cheaper generic product. Given that the consumer's switching cost only has to be paid once, that cost will obviously be less important the greater the number of additional purchases the consumer plans to make, since the same switching cost is amortized over a larger number of future purchases. ${ }^{202}$

What this means, in short, is that the switching cost story breaks down almost completely if consumers have infinitely long time horizons. This im turn implies that patentees will not have any reason to cultivate brand loyalty while the patent is in effect, since the post-expiration return from doing so is only a tiny fraction of the switching cost instead of the full switching cost.

Instead of assuming that consumers compare the current switching cost with the present discounted value of their future savings from switching, however, we might plausibly make the opposite assumption: that consumers are myopic. ${ }^{203}$ In this case, the patentee's maximum post-expiration price would rise to $S+P_{c}$, reflecting the full value of the switchimg cost. In sum, brand loyalty is only significant in an infinite-horizon model if we assume that consumers are not forward-looking.

\section{Pre-Expiration Dynamics}

Knowing that the post-expiration price will be $(1-\delta) S+\delta P_{c}$ in each period, the patentee will be in position to plot her optimal quantity during the patent period. There are, however, two addi-

${ }^{202}$ For an interest rate of $5 \%$, this means that the patentee can charge no more than approximately $0.05 S+.95 P_{c}$. In other words, the switching cost loses $95 \%$ of its "frictional" value when consumers are infinitely-lived and forward-looking.

${ }^{203}$ This is a standard assumption in the switching cost literature. See, e.g., Gabszewicz et al., supra note 71, at 399 (assuming that consumers do not take future switching costs into account when making decisions about present consumption plans). 
tional complications. First, the future revenue stream of $(1-\delta) S+\delta P_{c}$ each period from the expiration of the patent onwards must be discounted to its present value as of Period 21. This involves dividing by the imterest rate, $r$, to capture the infinite nature of the revenue stream. ${ }^{204}$

Second, an increase im Period- $t$ output will have a different effect on the present value of future profits depending on when it occurs.

Let $Q=(1 / 20) \sum_{t=1}^{20} Q_{t}$ be the

average output over the twenty-year patent life. An increase of one unit in any period will raise $Q$ by $1 / 20$ of a unit, but its discounted effect on post-expiration profits depends on when during the twenty years the increase occurs. Starting from the monopoly optimun, a one-unit increase in Period-20 output lowers profits in Period 20, but raises profits the next period, after the patent lapses by adding to $1 / 20$ of a unit to the stock of loyal customers. By contrast, an increase in Period-1 output lowers profits immediately, but does not raise profits until the patent expires twenty years hence. Thus, we must discount future profits caused by a Period- $t$ mcrease in output by $\delta^{21-t}$ to bring this future revenue stream to its Period- $t$ value (and then furtlier discount to bring this stream to its Period-0 value).

Hence, the patentee's full problem is:

$$
\underset{Q_{t}}{\operatorname{Max} \Pi}=\sum_{t=1}^{21}\left(a-b Q_{t}\right) Q_{t} \delta^{t}+\left(\frac{Q_{t}}{20}\right)\left(\frac{\delta P_{c}+(1-\delta) S}{r}\right) \delta^{21-t}
$$

which is solved by setting

$$
\frac{\partial \Pi}{\partial Q_{t}}=a \delta^{t}-2 b Q_{t} \delta^{t}+\frac{\delta^{21-t}\left(\delta P_{c}+(1-\delta) S\right)}{20 r}=0 \text {. }
$$

This implies that the optimal quantity at time $t, Q_{t}^{*}$, solves

${ }^{204}$ See supra note 199. 


$$
Q_{t}^{*}=\frac{a}{2 b}+\frac{\frac{\delta^{21-t}\left(\delta P_{c}+(1-\delta) S\right)}{20 r}}{2 b \delta^{t}},
$$

where $a$ and $b$ are the intercept and slope parameters from the demand curve, and the other parameters are defined above.

Note that the first term in the expression for $Q_{t}{ }^{*}$ is just the singleperiod monopoly output, $a / 2 b$, which is not time dependent. The second term is strictly positive and an increasing fuuction of time, from which we easily conclude that:

1. The trademark-leveraged patentee will always produce more than the "pure" patentee in every period; and

2. Optimal output rises over time during the patent period.

These results are entirely consistent with our two-period model. The chief difference is that if we assume consumers are forwardlooking in the sense described above, the patentee can only charge $\delta P_{c}+(1-\delta) S$, rather than $\left(P_{c}+S\right)$, and the leverage effect is correspondingly diminished.

As the figure im the text-which is drawn assuming that consumers are not forward-looking-illustrates, optimal output in the first year of the patent's life is only infinitesinially greater than the single-period monopoly level. As expiration approaches, however, output rises to more than $30 \%$ above the single-period monopoly level. Our story is thus at least roughly consistent with the dynamics of the case studies, in which patentees seem to reserve the bulk of their price cutting and attenipts to build market share for the patent's twilight years. 